\title{
The Invasive Species Challenge in Estuarine and Coastal Environments: Marrying Management and Science
}

\author{
Susan L. Williams • Edwin D. Grosholz
}

Received: 18 September 2007 /Revised: 17 December 2007 / Accepted: 18 December 2007 /Published online: 12 January 2008

(C) Coastal and Estuarine Research Federation 2007

\begin{abstract}
Despite the widely acknowledged threat posed by invasive species in coastal estuaries, there are substantial gaps at the intersection of science and policy that are impeding invasive species management. In the face of pressing management needs in coastal and estuarine environments, we advocate that introduced species should receive the kind of management effort dedicated, for example, to reducing pollution. We support our argument with some examples of economic costs of estuarine and coastal introduced species and a summary of recent evidence for the ecological costs. We highlight some of the issues that either thwart or facilitate the successful marriage between science and management of introduced species, including the regulatory framework for management. We use the available information on coastal eradication programs, including case histories of the programs for Caulerpa taxifolia and Spartina alterniflora (and hybrids) in the western USA, to indicate the feasibility of managing introduced species and to help point out how management and science can improve the outcome. We close with a research agenda that focuses primarily on science that will really assist with invasive species management and reflects
\end{abstract}

Contribution no. 2402 from the Bodega Marine Laboratory, University of California-Davis

S. L. Williams $(\bowtie)$

Bodega Marine Laboratory \& Section of Evolution and Ecology,

University of California at Davis,

Bodega Bay, CA 94923-0237, USA

e-mail: slwilliams@ucdavis.edu

E. D. Grosholz

Department of Environmental Science and Policy,

University of California at Davis,

Davis, CA 95616, USA

e-mail: tedgrosholz@ucdavis.edu our own experience and the opinions of managers directly involved with this issue.

Keywords Marine invasive species · Eradication · Economic costs $\cdot$ Management $\cdot$ Caulerpa $\cdot$ Spartina

\section{Introduction}

In this essay, we advocate that introduced species in coasts and estuaries should be managed with the same resolve dedicated to overexploitation, pollution, and climate change. We define an introduced species as having been introduced outside its native range through human activities; invasive species are a subset that are likely to, or cause economic or ecological harm. Estuaries and coasts are particularly susceptible to introductions of nonnative species partly a consequence of being centers for the activities that represent the major vectors for introductions: shipping and boating (Carlton and Geller 1993; Ruiz et al. 2000a); aquaculture (Naylor et al. 2001); aquarium trade (Padilla and Williams 2004); live seafood and bait (Chapman et al. 2003; Weigle et al. 2005). Research has progressed from identifying new introductions and determining the origin and probable vector to addressing the ecological effects of the introductions (Ruiz et al. 1999; Grosholz 2002). The media has heightened public awareness by trumpeting many cases, including the cholera virus transported in ballast waters (BBC News, 1 Nov. 2000), the 'Killer Alga' (Caulerpa taxifolia) invasions of the Mediterranean, California, and Australia (Simons 1997; Perlman 2000), and recently, pythons in the Florida Everglades (Revkin 2007). Despite this increased scientific interest and public awareness, research articles on introduced species are relatively few and tend to be published in general 
marine journals compared to ones specializing in estuaries and coasts (Fig. 1). We suggest this finding indicates that introduced species are not a sufficiently high priority for many scientists and managers dedicated to estuarine and coastal environments.

We begin this essay by reviewing progress toward management of invasive species in estuaries and coasts and why progress has not been faster, starting with the regulatory framework for management. We play the devil's advocate by asking whether slow progress even matters in the face of other pressing environmental perturbations to coasts and estuaries, at the risk of inciting our colleagues. We forego reviewing the relevant literature on the numbers of introduced species in estuaries and in coastal waters, which has been done well by others (Eno et al. 1997; Ruiz et al. 2000a; Ruiz and Carlton 2003; Streftaris et al. 2005). Instead, we provide new summaries of economic impacts of introduced species and eradication programs, along with our personal perspectives gained while serving as scientific advisers to two eradication efforts in the USA. Thereafter, we outline a research agenda aimed at providing the science needed by resource managers faced with invasive species. Several recent reviews have emphasized the need for more research on a number of topics of more basic interest to ecologists and evolutionary biologists, with limited application to on-the-ground management (Mack et al. 2000;

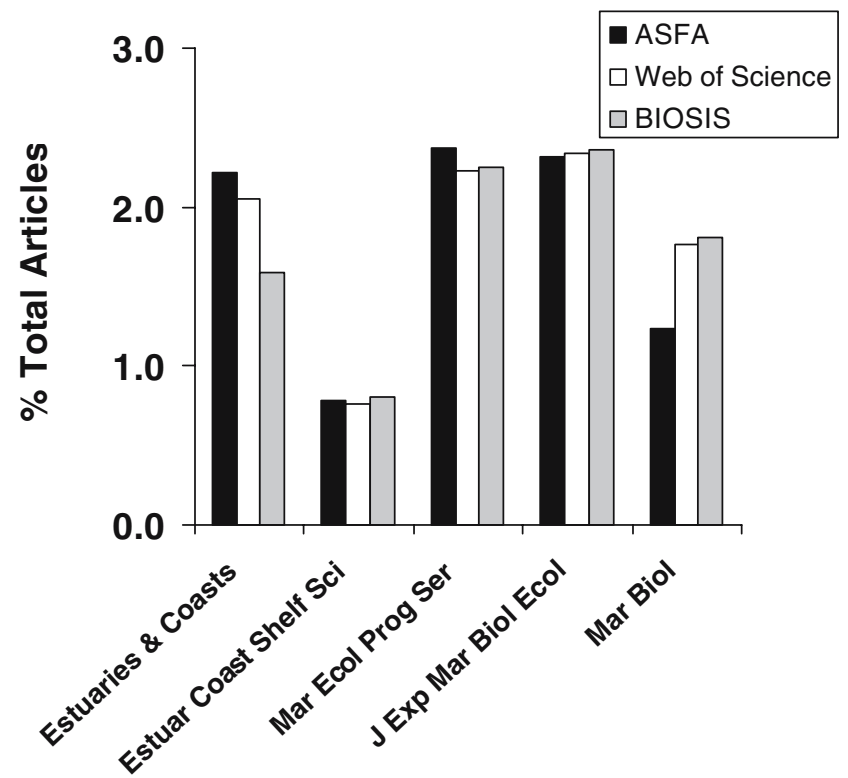

Fig. 1 Scientific publications on introduced species in estuarine and coastal versus general marine journals as percent of total number of articles published from 2000-2006. Results from searches using Aquatic Sciences and Fisheries Abstracts (ASFA), Web of Science, and BIOSIS. The total number of articles published and indexed by the Web of Science were: Estuaries and Coasts (535), Estuarine Coastal Shelf Science $(1,189)$, Marine Ecology Progress Series $(2,776)$, Journal of Experimental Marine Biology and Ecology $(1,195)$, Marine Biology $(1,307)$. Estuaries and Coasts was not indexed by BIOSIS until 2004
Sax et al. 2005, 2007). Our goal here is to outline a science agenda that will bring the needed science into the management decision process. Many scientists are increasingly interested in contributing to management projects, beyond publishing in journals that busy managers have scarce time to read. Because the cultures and timelines for meaningful results for the two groups are so different, we hope that this essay will provide a perspective that might be useful as scientists head into the management arena. For example, familiarity with the regulatory framework for management can help scientists communicate better with their manager colleagues. Many calls for action are available (e.g., Carlton 2001; Lodge et al. 2006), so we only reinforce recommendations for the management of high-priority introduced species through prevention, early detection, rapid response, and, if these fail, eradication or control.

\section{Progress Toward Management: The Regulatory Framework}

Australia and New Zealand stand out among nations in taking proactive approaches to dealing with the prevention, eradication, and control of invasive marine organisms. These countries have experienced obvious severe impacts to the endemic biotas they take pride in and consequently, their federal and regional governments have made substantial investments in invasive species management. For instance, in the 1990s, Australia created the Center for Research on Invasive Marine Pests (CRIMP) within the Commonwealth Scientific and Industrial Research Organization (CSIRO), which led to the Introduced Marine Pest Coordination Group, which leads the management efforts. Marine scientists and resource managers also attribute a more coordinated federal management approach to a small number of sovereign provinces, unlike in the USA or Europe. The approach to the management of introduced species in these countries is strongly science-based, easily evident in the number of scientific journal articles contributed by agency scientists and the data-rich management plans readily accessible through the internet.

In contrast, in the USA, the federal government has not created a similar centralized agency that has had the necessary resources or the authority for nimble management of introduced species. Intergovernmental structures, such as the Aquatic Nuisance Species Task Force created in 1990 and the National Invasive Species Council created in 1999, have been slow to move forward with their plans, including the national Invasive Species Management Plan of 2001. This situation has left states to act independently in areas such as regulating ballast waters, aquaculture, and the aquarium trade (e.g., Brown et al. 2005). The lack of federal leadership has created overlapping mosaics of 
federal and state regulations, which are difficult for affected stakeholders to navigate and have led to lawsuits over ballast water regulation.

The European Union seems equally uncoordinated as individual countries forge their own approaches to introduced species in coastal and estuarine communities within the same body of water (Manchester and Bullock 2000; Council of Europe 2004) or lack resources for management (Genovesi 2005). That said, many European nations have signed the Convention on Biodiversity (CBD), which the USA has not, and the Codes of Practice on the Introductions and Transfers of Marine Organisms set by the International Counsel for Exploration of the Seas (2005). These policies provide some of the most comprehensive guidelines for preventing deliberate introductions of invasive species.

For nations intent on preventing injurious effects of introduced species, more than 50 international and regional legal instruments exist that address the intentional introductions of nonnative species, including the CBD (Shine et al. 2000; Hewitt and Campbell 2007). However, few are binding or carry penalties for noncompliance. The only convention where costs of noncompliance are potentially heavy enough to deter introductions is the Agreement on the Application of Sanitary and Phytosanitary Measures (SPS) under the World Trade Organization. When nations such as New Zealand attempt to regulate introductions of potentially invasive species, they must do so without impeding trade (Jenkins 1996) and they carry the cost of the required risk assessment (Hayes 2003). Adjudication of SPS cases has favored the exporting nations (Pauwelyn 1999). In the face of trade restrictions on biosecurity, even Australia and New Zealand are limited in their attempts to achieve better outcomes for their coastal and estuarine resources.

The existing legal instruments concerning invasive species focus heavily on preventing introductions. Preventing introductions of nonnative species and acting quickly when a potentially invasive one slips through the screen is undoubtedly the best way to reduce future costs of management (McNeely et al. 2003). Why then has there been so little prompt action in estuaries and along coasts (Defenders of Wildlife 2007), with the notable exceptions in Australia and New Zealand? We propose several reasons for the lack of prompt action. The stakeholders, e.g., fishermen and recreational users, who would typically advocate for increased protection of coastal resources, are a singularly dispersed group, and the effects of these introductions are rarely evident to them. In contrast, the shipping, aquaculture, aquarium, live seafood, and live bait industries stand to lose from attention that leads to increased regulation. Aquaculturists have small profit margins, which ironically can be reduced to nonviability from species introduced through the business (e.g., Terebrasabella uncinata infestation of California abalone farms, Culver and Kuris 2000).

Because the economic impact of introduced estuarine and coastal species are understudied and mostly qualitative (Table 1), in comparison to damage from introduced crop pests, the incentive to manage is proportionally reduced. Externalities, which are the costs to society or native biota above identifiable direct costs associated with the specific economy (aquaculture products, eradication programs), are notoriously difficult to estimate, particularly in the marine environment (Margolis et al. 2005).

\section{Why Allocate Precious Resources to Introduced Species in the Coastal Environment?}

Would resources be better spent on reducing other anthropogenic influences on estuaries and coasts, such as overexploitation, pollution, eutrophication, and increased hypoxia, as opposed to introduced species? After all, the effects of pollution can ramify through the food web to reach human consumers, and severe eutrophication can spill downstream to profoundly influence extensive areas of deeper marine environments, as has occurred in the Gulf of Mexico (Mitch et al. 2001). And, sea level rise under global warming looms as a pressing issue to address, with its predicted profound effects on coastal societies and ecological communities around the world (Michener et al. 1997; Nicholls and Lowe 2004; Kerr 2006).

In the face of such critical issues and the largely uncertain economic consequences of introduced species (although the economic impact of the other issues are equally unquantified), it might seem hard to argue that introduced species should be a top priority of concern. The companion ecological argument that introduced species have negative effects on marine and estuarine species, communities, ecosystems, and resources often has relied heavily on anecdotal evidence (Reise et al. 2006; Galil 2007). Now, however, as evidence accumulates, it is clearer that introduced species in coastal and estuarine waters largely have negative effects, although good economic assessments for introduced marine and estuarine species are still lacking. Recent reviews provide evidence that the majority of introduced marine and estuarine species that have been studied rigorously have quantifiable negative effects on native species, including protected ones such as seagrasses (Grosholz 2002; Williams 2007; Williams and Smith 2007). The link between introduced marine and estuarine species and human health risks is increasingly evident as pathogens (Ruiz et al. 2000b) and toxic dinoflagellates (Hallegraeff 1998) are being found in ballast waters or can hitchhike on other invasive species (e.g., Oriental lung fluke, Paragonimus westermanii, in native 
Table 1 Examples of economic impacts of introduced estuarine and marine species

\begin{tabular}{|c|c|c|c|}
\hline Introduced Species & Economic Impact & Estimated Cost & Reference \\
\hline \multicolumn{4}{|l|}{ Seaweeds } \\
\hline $\begin{array}{l}\text { Caulerpa taxifolia } \\
\text { killer algae }\end{array}$ & Eradication & $>$ US\$6M (6 year) & Authors \\
\hline \multirow[t]{2}{*}{$\begin{array}{c}\text { Codium fragile v. tomentosoides } \\
\text { oyster thief, deadman's fingers }\end{array}$} & $\begin{array}{l}\text { Cultured oyster mortality, kelp } \\
\text { valuation }\end{array}$ & $\mathrm{C} \$ 1,500,000 / \mathrm{yr}$ & Colautti et al. 2006 \\
\hline & Removal from native seaweed farm & Bankruptcy & Neill et al. 2006 \\
\hline Hypnea musciformis & $\begin{array}{l}\text { Removal } \\
\text { Reduced property values }\end{array}$ & US\$55,000 & Van Beukering and Cesar 2004 \\
\hline $\begin{array}{l}\text { Undaria pinnatifida } \\
\text { Wakame }\end{array}$ & Eradication & NZ\$2,923,500 (total) & Wotton et al. 2004 \\
\hline \multicolumn{4}{|l|}{ Invertebrates } \\
\hline $\begin{array}{l}\text { Carcinus maenas } \\
\text { European green crab }\end{array}$ & Reduces bivalve aquaculture & US $\$ 22 \mathrm{M} / \mathrm{yr}$ & $\begin{array}{l}\text { Grosholz et al. 2000, Lovell et al. } \\
2007\end{array}$ \\
\hline $\begin{array}{l}\text { Eriocheir sinensis } \\
\text { Chinese mitten crab }\end{array}$ & Invasion of fish salvage facility & US\$1M (2000) & $\begin{array}{l}\text { Aquatic Nuisance Species Task } \\
\text { Force } 2003\end{array}$ \\
\hline $\begin{array}{l}\text { Mnemiopsis leidyi } \\
\text { Ctenophore }\end{array}$ & Correlated loss of anchovy fishery & $\mathrm{US} \$ 250 \mathrm{M} / \mathrm{yr}$ & Zaitsev 1992 \\
\hline $\begin{array}{l}\text { Mytilopsis sallei } \\
\text { black striped mussel }\end{array}$ & Eradication & $\mathrm{A} \$ 2.2 \mathrm{M}$ & Bax et al. 2002 \\
\hline $\begin{array}{l}\text { Phyllorhiza punctata } \\
\text { Scyphomedusa }\end{array}$ & Potential loss in shrimp landings & US\$10M (2000) & Graham et al. 2003 \\
\hline \multirow[t]{2}{*}{$\begin{array}{l}\text { Terebrasabella heterouncinata } \\
\text { Sabellid polychaete }\end{array}$} & $\begin{array}{l}\text { Reduced cultured abalone product } \\
\text { quality }\end{array}$ & Bankruptcy & Culver and Kuris 2000 \\
\hline & Eradication & Several US\$K & Kuris 2003 \\
\hline $\begin{array}{l}\text { Teredo navalis } \\
\text { Shipworm }\end{array}$ & Structural damage (ships, docks) & US\$200M/yr & Cohen and Carlton 1995 \\
\hline
\end{tabular}

populations of Chinese mitten crabs, Eriocheir sinensis). There is also evidence that certain introduced species can accumulate higher levels of contaminants than native species (e.g., the Asian clam, Corbula amurensis, in San Francisco Bay, Richman and Lovvorn 2004). New data also indicate that introduced species are among the top factors associated with threatening or endangering marine species (sea birds, sea turtles, fishes) with extinction (Kappel 2005; Venter et al. 2006). Obviously, extinctions are irreversible, unlike pollution and eutrophication. In addition to the specter of extinction, other effects of species introduced to estuaries and coasts can be reversed only with great effort, if at all. The options for effective management are more limited than in terrestrial environments (see section on eradication and control research needs).

In the near universal absence of effective prevention (Simberloff 2005), the management options are reduced to eradication and control. However, the situation is not hopeless. We will present evidence (Table 2) to dispel a common misconception that managing established invasive species in marine systems is not very feasible. Marine invasive species do not inevitably spread rapidly and extensively beyond control (Thresher and Kuris 2004). In fact, there are many examples of introduced species that have not spread far beyond the initial site of introduction and other species that are a significant problem in one estuarine system have not spread beyond that estuary (e.g., Ilyanassa obsoleta and Guekensia demissa have been restricted to certain areas within California for decades). For the invasive ones, eradication, which is less costly than prolonged control programs, can be feasible in the early stages of invasion when the distribution of the invader is limited. Time lags between introduction and spread allow a window of opportunity, if the species can be detected (Crooks 2005). Feasibility has been demonstrated by several recent programs in coastal marine and estuarine environments (Table 2). Feasibility aside, we emphasize that prevention is the best management policy.

These examples of eradication programs for marine and estuarine introduced species likely represent most of the documented programs; we contacted colleagues and introduced species list-serves and searched the internet extensively. Europe has attempted few eradications in general, let alone in marine environments, which is considered a result of limited awareness, legal frameworks, and resources (Genovesi 2005). If Europe has not mounted concerted efforts, the situation is worse for developing regions of the world. We did not include small geographically restricted 
Table 2 Examples of eradication programs for introduced estuarine and coastal marine species, listed in chronological order

\begin{tabular}{|c|c|c|c|c|}
\hline Introduced Species & Eradication Site & $\begin{array}{l}\text { Date } \\
\text { Initiated }\end{array}$ & Status & Reference \\
\hline $\begin{array}{l}\text { Thais clavigera } \\
\text { Japanese oyster drill }\end{array}$ & $\begin{array}{l}\text { British Columbia, } \\
\text { Canada }\end{array}$ & 1951 & Successful & Carlton 2001 \\
\hline $\begin{array}{l}\text { Spartina anglica } \\
\text { hybrid cordgrass }\end{array}$ & Ireland & $1960 \mathrm{~s}$ & Unsuccessful; reverted to control & Hammond and Cooper 2002 \\
\hline $\begin{array}{l}\text { Macrocystis pyrifera } \\
\text { Giant kelp }\end{array}$ & Hawaii, USA & $\begin{array}{l}1972 \\
1980 \mathrm{~s}\end{array}$ & Successful & Shluker 2003 \\
\hline $\begin{array}{l}\text { Sargassum muticum } \\
\text { Wireweed }\end{array}$ & England & $\begin{array}{l}1973 \\
1976\end{array}$ & Unsuccessful & Carlton 2001 \\
\hline $\begin{array}{c}\text { Avicennia marina } \\
\text { black mangrove }\end{array}$ & California, USA & 1980 & Completed 2000; reappeared 2006 & Kay et al. 2006 \\
\hline $\begin{array}{l}\text { Spartina alterniflora, } \\
\text { S. anglica, and hybrids } \\
\text { cordgrasses }\end{array}$ & New Zealand & 1987 & $\begin{array}{l}\text { Successful in Southland; ongoing } \\
\text { elsewhere }\end{array}$ & $\begin{array}{l}\text { http://www.biodiversity.govt. } \\
\text { nz/news/ } \\
\text { media/current/05nov04.html } \\
\text { (accessed 14 December 2007) } \\
\text { Krikwoken and Hedge } 2000\end{array}$ \\
\hline $\begin{array}{l}\text { Spartina alterniflora, S. patens, } \\
\text { and hybrids }\end{array}$ & Oregon, & 1990 & Completed one site; ongoing & Pfauth et al. 2003 \\
\hline cordgrasses & $\begin{array}{l}\text { Washington, } \\
\text { California, U.S }\end{array}$ & $\begin{array}{l}2003 \\
2005\end{array}$ & & $\begin{array}{l}\text { Murphy et al. } 2007 \\
\text { Olofson et al. } 2007\end{array}$ \\
\hline $\begin{array}{l}\text { Asterias amurensis } \\
\text { Northern Pacific seastar }\end{array}$ & Victoria, Australia & $\begin{array}{l}1993 \\
2002\end{array}$ & $\begin{array}{l}\text { Unsuccessful in Port Phillip Bay; near } \\
\text { completion at Inverloch }\end{array}$ & Dommisse and Hough 2004 \\
\hline $\begin{array}{l}\text { Perna canaliculus } \\
\text { green lipped mussel }\end{array}$ & South Australia & 1996 & Successful & Bax and McEnnulty 2001 \\
\hline $\begin{array}{l}\text { Terebrasabella heterouncinata } \\
\text { sabellid parasite of abalone }\end{array}$ & California, USA & 1996 & Successful & Culver and Kuris 2000 \\
\hline \multirow[t]{3}{*}{$\begin{array}{l}\text { Undaria pinnatifida } \\
\text { wakame seaweed }\end{array}$} & $\begin{array}{r}\text { Tasmania, } \\
\text { Australia }\end{array}$ & 1997 & Ongoing & Hewitt et al. 2005 \\
\hline & $\begin{array}{l}\text { Catham Islands, } \\
\text { New Zealand }\end{array}$ & 2001 & Successful & Wotton et al. 2004 \\
\hline & California, USA & 2002 & Unsuccessful; reverted to control & Lonhart 2003 \\
\hline $\begin{array}{l}\text { Mytilopsis sallei } \\
\text { black-striped mussel }\end{array}$ & $\begin{array}{l}\text { Northern Territory, } \\
\text { Australia }\end{array}$ & 1999 & Successful & Bax et al. 2001 \\
\hline $\begin{array}{l}\text { Caulerpa taxifolia } \\
\text { 'killer' algae }\end{array}$ & California, USA & 2000 & Successful & Authors \\
\hline $\begin{array}{l}\text { Ascophyllum nodosum } \\
\text { Atlantic rockweed }\end{array}$ & California, USA & 2002 & Successful & Miller et al. 2004 \\
\hline $\begin{array}{l}\text { Didemnum vexillum } \\
\text { colonial sea squirt }\end{array}$ & New Zealand & 2003 & Unsuccessful in some areas; ongoing & Coutts and Forrest 2007 \\
\hline $\begin{array}{l}\text { Zostera japonica } \\
\text { Japanese eelgrass }\end{array}$ & California, USA & 2003 & Ongoing & Eicher 2006 \\
\hline $\begin{array}{l}\text { Littorina littorea } \\
\text { periwinkle snail }\end{array}$ & California, USA & 2005 & Near completion & $\begin{array}{l}\text { Chang et al. personal } \\
\text { communication }\end{array}$ \\
\hline $\begin{array}{l}\text { Batillaria attramentaria } \\
\text { horn snail }\end{array}$ & California, USA & 2006 & Ongoing at 2 sites & $\begin{array}{l}\text { Weiskel and Zabin personal } \\
\text { communication }\end{array}$ \\
\hline $\begin{array}{l}\text { Carcinus maenas } \\
\text { European green crab }\end{array}$ & California, USA & 2006 & Ongoing & Grosholz et al. unpublished \\
\hline
\end{tabular}

eradications, such as for Caulerpa taxifolia in the Mediterranean or Australia, because the invasions overall are so extensive that even control will be difficult (Meinesz et al. 2001; Collings et al. 2004), although these efforts provide critically valuable information for a new restricted infestation. Nor did we include specific feasibility trials such as the mechanical removal of invasive seaweeds with a suction device (supersucker) to control them in Hawaii (Coordinating Group for Alien Pest Species 2006).

The outcome of these eradication programs has been varied but generally predictable. Successes occurred when the introduced populations were small and restricted, human and financial resources were available, and early action was taken, exactly the criteria predicted for success (Myers et al. 2000). 
When eradication proved unfeasible, information gained then fed into fall-back control programs (Asterias, Spartina in Great Britain, also see Cheshire et al. 2002 for Caulerpa). Both 'gold-standard' successes (Mytilopsis in Australia; Caulerpa in California) were highly coordinated by cooperating government agencies committed to the goal of total eradication and undertaken early when populations were restricted. Another point evident from our compilation is the number of the examples (Ascophyllum, Avicennia, Batillaria, Littorina, Macrocystis, Perna, Terebrasabella) conducted by nonagency scientists. In the case of Perna, a cluster of mussels was found attached to a single fish, which was removed by a research diver (Bax and McEnnulty 2001).

To assess how managers viewed the role of science in these programs (Table 3), we queried them about what was useful from the scientific community and what would the managers have liked in addition, and supplemented their responses with formal evaluations of programs (Ferguson 2000; Bax et al. 2006). Managers were in consensus that access to experts and basic biological and ecological information was critical to managing the eradications and more was desirable (see Research Agenda). Managers also relied on scientists to provide eradication success/failure benchmarks and reviews of programs to facilitate adaptive management. They recommended that these roles for scientists be formalized early in programs. Risk assessment and cost-benefit analyses were useful even if qualitative; the more extensive the scientific evidence for the risk, the easier it was to take or defend management actions. Clearly, scientists need to undertake more quantitative risk assessment and develop and assess alternative treatment technologies. Interestingly, several managers pointed out a slow or absent response from their agencies in supporting their on-the-ground efforts.

In the next section, we provide an insider's view of case histories of eradication programs for two introduced species. We want to provide a sense of how an eradication program is shaped by the regulatory framework for management and where and how science can contribute to the success of the management process.

\section{Two Case Histories: The Introductions of Caulerpa and Spartina}

Caulerpa taxifolia (Mediterranean aquarium strain) The eradication of the invasive seaweed Caulerpa taxifolia in southern California is held up as a gold standard of estuarine and marine invasive species management, along with the earlier eradication of the black striped mussel in Australia. When Caulerpa taxifolia, considered one of the world's top 100 invasive species (Lowe et al. 2004), was identified in a native eelgrass bed in southern California in 2000, an ad hoc advisory team immediately began an eradication program (Anderson 2005) and success was declared in 2006. The rapid response proceeded in part because of the attention the species received, first from scientists, since it was found in 1984 in the Mediterranean (Meinesz 1999), where it had spread too far to consider eradication (Meinesz et al. 2001). At the prompting of scientists, Caulerpa taxifolia had been placed on the US Noxious Weed list in 1999, which provided the United States Department of Agriculture (USDA) with the authority to prohibit importation and interstate transfer of the Mediterranean clone of $C$. taxifolia and to treat the introduction as an emergency. However, the authority to take action does not insure a response, which the $C$. taxifolia example brought to light. In this case, eradication would not have proceeded without a self-appointed ad hoc management team SCCAT (Southern California Caulerpa Action Team) of exceptionally committed local and

Table 3 Perspectives of managers on the contribution of science/scientists to eradication programs

\begin{tabular}{|c|c|}
\hline What was useful to eradication management? & What else would be/has been useful from the scientific community? \\
\hline Access to biological/ecological information on the species & $\begin{array}{l}\text { Further research relevant to invaded range (long-term effects, restoration } \\
\text { requirements) }\end{array}$ \\
\hline $\begin{array}{l}\text { Risk assessments (informal, formal), particularly for likelihood of } \\
\text { spread and control efficacy }\end{array}$ & $\begin{array}{l}\text { Easier access to information through databases (bibliographic, treatment } \\
\text { strategies/alternatives, scientific experts) }\end{array}$ \\
\hline Identification of the introduction and taxonomic verification & Coordinated surveys and mapping \\
\hline $\begin{array}{l}\text { Access to information on previous management programs (or for } \\
\text { similar species) }\end{array}$ & Earlier results \\
\hline $\begin{array}{l}\text { Lab and limited field studies on control strategies for local } \\
\text { conditions }\end{array}$ & Early definition of respective roles of scientists and managers early \\
\hline Scientific benchmarks, review, and recommendations & Improved certainty of data \\
\hline Monitoring, including ecosystem function & General guidelines for eradication of new infestations \\
\hline Articulate media communications & Cost-benefit analyses \\
\hline \multirow[t]{2}{*}{ Vector analysis } & More information on threat \\
\hline & Vector analysis \\
\hline
\end{tabular}


regional managers, seeded by funding provided by a responsible corporation. In addition to managing and seeking funding for the eradication and the public education program, SCCAT was forced to sort out lines of authority and relevant regulations (e.g., for chemical applications).

Agencies with strikingly different experiences and practices came together in the case of Caulerpa taxifolia. The federal and state agricultural agencies advocated rapid deployment of chemicals as practiced successfully on land, but the suite of herbicides effective for controlling freshwater nuisance plants does not work for $C$. taxifolia (Anderson et al. 2005). Copper, which is toxic to $C$. taxifolia (Uchimura et al. 2000), is regulated as a marine pollutant and its application could have serious nontarget effects. When copper treatment was considered, the USA Fish and Wildlife Service (USFWS) objected. The USFWS and other collaborating agencies experienced in marine environments but not in eradication were attuned to the concerns of a marine conservation constituency. An action-delaying impasse was luckily avoided.

Because listing under the federal Noxious Weed Act did not provide adequate protection against repeated invasions, California also passed legislation prohibiting the possession and sale of C. taxifolia and other species of Caulerpa easily confused with $C$. taxifolia or known or suspected to have invasive potential, to bridge gaps in relevant federal legislation (Withgott 2002). California attempted to ban the entire genus Caulerpa because of mounting evidence of ecological risks, widespread availability (Walters et al. 2006), troublesome identification to species (Fig. 2), and the threat of spread beyond tropical regions (Zaleski and Murray 2006). Despite the scientific evidence to ban the genus, the aquarium trade (the known vector for the

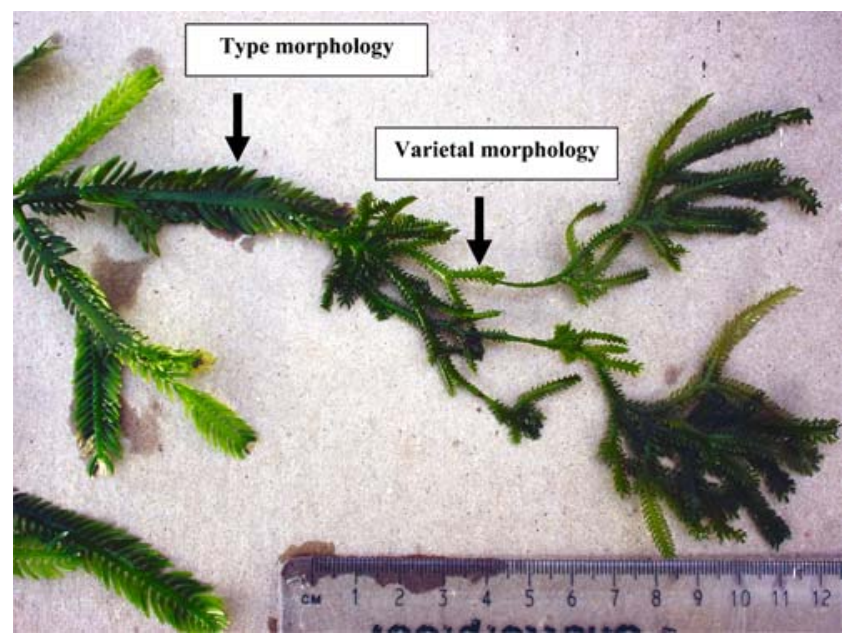

Fig. 2 Caulerpa taxifolia from Huntington Harbor, California, showing morphological variation ranging from the type form to forms more closely resembling $C$. cupressoides var. lycopodium f. elegans. Such morphological variation makes species identification, and thus regulation, difficult; photo by $B$. Nyden introduction, Jousson et al. 1998) mounted a successful campaign to amend the bill to a few species, few of which can be identified reliably by enforcement agents, thus creating a loophole for $C$. taxifolia to re-enter California. Although California's efforts at a genus-level ban failed, USDA is considering genus-level bans for the first time because definitive specific identification is also a problem for an invasive aquatic plant (Giant Salvinia, S. molesta). Ecological data on invasiveness were sufficient to support a genus-level listing for both genera. Yet, the agency still has not responded to the Caulerpa petition submitted in 2003 requesting the action, despite the recommendations of agency biologists and the National Caulerpa Management Plan. USDA is worried about setting a precedent and also not having sufficient funds to enforce a genus-wide listing. Despite state and federal regulation, the prohibited Caulerpa species are still being sold in California (Zaleski and Murray 2006), slip through customs (W. Paznokis and S. Ellis, California Department of Fish and Game, personal communication), and are widely available through internet commerce (Walters et al. 2006). The Pet Industry Joint Advisory Council, which represents the aquarium industry, has been slow to follow through with a commitment to step up public education campaigns. It seems only a matter of time before C. taxifolia or another weedy Caulerpa species becomes established again.

When that happens, managers will seek information from the California effort. Unfortunately, the opportunity to collect valuable field data in support of the management effort, as recommended by scientists (Dalton 2000, 2001), was largely missed. Scientists did not recommend delaying eradication in order to study C. taxifolia (Anderson 2005), but rather that data should be collected as the eradication proceeded. No delay in eradication was necessary because a full year was required to treat all infested areas. There were lost opportunities to measure the relative efficacy of light reduction versus chlorine in the eradication (Williams and Schroeder 2004), which would have provided a basis to potentially reduce hazardous chlorine applications near urban settlements, residual chemical effects on nontarget biota, and cost. Information on the temperature and light regimes and algal growth rates in infested areas also is not available, which would be invaluable to target areas of potential establishment and predict spread rates.

The eradication of Caulerpa taxifolia in the US contrasts with the situation in temperate Australia. When discovered in temperate Australia in 2000, it had already spread too widely to attempt eradication. Managers focused on controlling it with coarse sea salt in New South Wales, which was effective in small plots, had no residual effects on native biota 6 months later, but was prohibitively expensive for use in all invaded sites (Glasby et al. 2005). In South Australia, a river system was diverted into an 
infested artificial lake to lower the salinity (Cheshire et al. 2002; Collings et al. 2004). The massive effort was successful in a small area, but not in adjacent areas. The management priority has become controlling $C$. taxifolia at points of potential dispersal or new introductions, such as boat ramps and fishing sites. Although management could not be effected early enough to eradicate Caulerpa, Australian scientists and managers have provided some of the most rigorous data not only in support of management options but also on the ecological effects of introduced $C$. taxifolia (Davis et al. 2005; Gollan and Wright 2006; Gribben and Wright 2006a,b; York et al. 2006).

Spartina alterniflora Among the most extensive ongoing eradication efforts for an estuarine invasive species is the one focused on eastern cordgrasses Spartina spp. in western North America. The dramatic impacts of Spartina alterniflora and its hybrids on benthic food webs and ecosystem structure and function have been well documented in both San Francisco Bay (SFB), California (Neira et al. 2005, 2006, 2007; Brusati and Grosholz 2006, 2007; Levin et al. 2006) and Willapa Bay (WB), Washington (Zipperer 1996; O'Connell 2002; Tyler et al. 2007; Grosholz et al. in press). Spartina is also a significant threat to economies in both bays including loss of grow-out habitat for the commercial oyster production industry in WB and clogging of flood control channels and loss of water-front property values in SFB. As a result, multi-million dollar eradication programs have been undertaken in both estuaries (California Coastal Conservancy 2007; Murphy et al. 2007, Fig. 3).

The history of invasion proceeded very differently in California and Washington. In California, Spartina alterniflora was first introduced from its native range in eastern North America into SFB in 1975 by the Army Corps of Engineers for marsh restoration (Ayres et al. 2004). It has

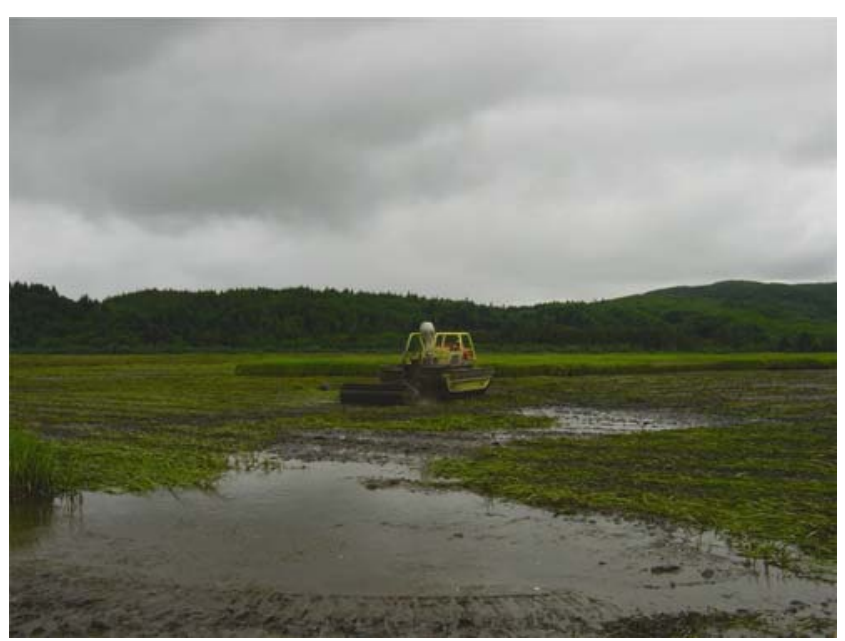

Fig. 3 Mechanized eradication of Spartina alterniflora in Willapa Bay, Washington since hybridized with the native S. foliosa (hybrid Spartina; Daehler and Strong 1997) producing a highly invasive strain that has now invaded approximately 800 ha of SFB, including extensive areas of open mudflat. In Washington, the invasion of WB began with the accidental introduction of Spartina alterniflora around 1890 (Feist and Simenstad 2000; Davis et al. 2004; Civille et al. 2005). Since then, it has rapidly colonized open mudflat and spread to cover more than 2,400 ha. This invasion is entirely the result of the spread of $S$. alterniflora; there are no hybrids.

Eradication efforts in Washington also proceeded differently than in California. In WB, the eradication program began in 1995 amid lack of coordination between various state and federal agencies. Cooperation and more effective eradication was enacted in 2003 such that nearly the entire bay was treated by 2007 (Murphy et al. 2007) and the rest (600 acres) is expected to be treated in 2008. In SFB, eradication of the nearly 300 ha invaded by hybrid Spartina has only been underway since 2005. Unlike in Washington, the program has been conducted by a single entity, the Invasive Spartina Project of the California Coastal Conservancy. The eradication program is expected to be effective, but accurate estimates of the success of eradication efforts in 2006 are not yet available.

Scientific investigations of the food web and ecosystem impacts of hybrid Spartina in SFB and WB (see citations above) were conducted mostly before the broad-scale eradication efforts and proceeded largely unimpeded by management, unlike in the Caulerpa taxifolia case where science was an afterthought. Also unlike the Caulerpa taxifolia case, there was little discussion or exchange among the scientists and managers, although there were several shared goals that could have been more productively addressed through cooperative action. Once eradication programs were initiated, collaborative research projects were outlined and conducted involving both scientists and managers in both states, largely at the behest of the scientists. In both states, the agencies conducting the eradication efforts agreed to avoid or delay spraying herbicide in focal sites under study during the previous years, to incorporate some of the research goals of the scientists. The results of these very limited collaborations between science and managers were mixed, although they did provide some experimental results. Unfortunately, conducting the agreed eradication procedures were complicated by problems with herbicide application. In addition, the objective of saving some unsprayed areas as controls was negated in part because of their small size relative to the large scale of the surrounding sprayed areas. Nevertheless, the Spartina examples demonstrate that the goals of science and management do not need to conflict.

A pressing question for managers attempting Spartina eradication under budget restrictions is where to start. 
Should eradication efforts focus on the center of the invasion where plants are dense and are presumably seeding future expansions or at the leading edge of the invasion where plant density is lower? Interestingly, the answer differs depending on the resources available to the eradication program (Taylor and Hastings 2004, 2005).

A second example stems from the manager's need to monitor recovery and if necessary, restore the previously invaded habitat (Blossey 1999). But how and at what rate will restoration of the system proceed once the invader has been eradicated? Research on the invasion and recovery of sites following Spartina eradication suggests that several factors including tidal elevation and sediment grain size strongly influence the rate of recovery and thus how quickly restoration of the pre-invasion condition will occur (Grosholz et al. in press; Tyler et al. 2007). The knowledge to prioritize which sites are most likely to be restored to the pre-invasion condition is invaluable under inevitable funding limitations.

Marrying Science and Management In hindsight, the Caulerpa and Spartina cases make it clear that the goals of the scientists and the managers were not far apart. Eradication and control should and can be done as adaptive management experiments (Myers et al. 2000), as demonstrated in the Australian management of the northern Pacific seastar (Asteria amurensis) and Caulerpa taxifolia (Cheshire et al. 2002, Bax et al. 2006). Most eradication programs require multiple years for completion, allowing for scientific study in small areas temporarily excluded from the overall eradication plan. 'Mopping up' these areas near the end of the eradication program will generally not create any obstacles for the ultimate goal of complete eradication. Effects of eradication and control on nontarget organisms should be part and parcel of every field effort to make choices among alternative eradication and control strategies. Invasive species management plans that explicitly integrate science with rapid response, control, and management in the field offer a more powerful outcome than relegating science to essentially an appendix, as has been done more often that not in the USA.

\section{Highlighting an Agenda for Management-Focused Research}

By any measure, the focus on invasive species and their impacts has clearly sharpened within the past decade (Mack et al. 2000; Sax et al. 2005, 2007). There has been a rapid emergence of new tools for managing invasive species (Lodge et al. 2006). However, because of the idiosyncratic nature of specific management needs and funding opportu- nities, there has been uneven coverage of the broad range of issues that need to be addressed to really strengthen prevention and management of invasions. In the research agenda to follow, we outline specific topics central to realizing the common goals of intelligent management of invasions and broad based learning about the invasion process.

Effects on Communities and Ecosystems The rationale for managing depends strongly on the impacts of an introduced species on the native biota. Over the past 15 to 20 years, ecological impacts have become a major focus of invasion research in coastal areas. However, most studies have focused on interactions between the introduced species and its immediate competitors, predators, and prey, typically species by species (reviewed by Grosholz 2002; Williams 2007; Williams and Smith 2007). Greater impacts accrue to invasions of particular functional groups (e.g., ecosystem engineers, filter feeders, large predators, Table 4, Crooks 2002; Wallentinus and Nyberg 2007), which provide a rough way to prioritize preventing introductions of species with highly undesirable characteristics. A more recent review of impacts across multiple trophic levels demonstrates that two functional groups in particular, ecosystem engineers and filter feeders, are the predominant groups responsible for impacts across trophic levels (Grosholz and Ruiz in press). Ecosystem engineers and filter feeders are also likely to have disproportionately strong impacts on system-wide biodiversity and ecosystem function. Clearly, there is a need to consider a much broader range of interactions and processes.

Ecosystem processes and functions are among the most overlooked effects of introduced species in estuarine and coastal environments. To date, only a handful of studies have measured the effects of invasive species on the cycling and storage rates of carbon and nitrogen in coastal systems (e.g., Larned 2003; Ruesink et al. 2005, 2006; Tyler et al. 2007; Williams and Smith 2007 for introduced seaweeds). Examples from the invasion of Spartina (see above) have shown that Spartina can significantly affect macroalgal production, increase storage of carbon and nitrogen in plant detritus, and cause a shift from a net autotrophic to a net heterotrophic system (Tyler and Grosholz, in review). Filter feeders in particular can produce profound effects on ecosystem function as demonstrated by the shift in primary production water column to the benthos after the introduced clam Corbula amurensis became abundant in San Francisco Bay (Alpine and Cloern 1992; Kimmerer et al. 1994).

Prevention Much research has been devoted to new methodologies to replace species-by-species assessments of the risk of deliberate introductions. A species-by-species risk approach is not very effective, as was made patently 
Table 4 Examples from major functional groups of concern for estuarine and coastal introduced species and their effects

\begin{tabular}{|c|c|c|c|}
\hline Type of Species & Example & Effect & Reference \\
\hline \multirow{3}{*}{$\begin{array}{l}\text { Clonal or } \\
\text { Weedy }\end{array}$} & Caulerpa taxifolia (seaweed) & Overgrows seagrasses & Ceccherelli and Cinelli 1997 \\
\hline & Caulerpa racemosa (seaweed) & Overgrows seagrasses & Ceccherelli and Campo 2002 \\
\hline & $\begin{array}{l}\text { Watersipora subtorquata } \\
\text { (bryozoan) }\end{array}$ & Fouls ship hulls and marinas & Floerl et al. 2004 \\
\hline \multirow[t]{2}{*}{ Predator } & Carcinus maenas (green crab) & Eats bivalves and crabs & Grosholz et al. 2000, 2001 \\
\hline & $\begin{array}{l}\text { Rapana venosa (veined whelk) } \\
\text { Asterias amurensis (seastar) }\end{array}$ & $\begin{array}{l}\text { Eats commercially important } \\
\text { bivalves }\end{array}$ & $\begin{array}{l}\text { Savini and Occhipinti-Ambrogi } 2005 \\
\text { Ross et al. } 2002\end{array}$ \\
\hline Filter feeder & Corbula amurensis (Asian clam) & $\begin{array}{l}\text { Reduces phytoplankton } \\
\text { Correlates with zooplankton declines }\end{array}$ & Alpine and Cloern 1992; Kimmerer et al. 1994 \\
\hline \multirow[t]{4}{*}{$\begin{array}{l}\text { Ecosystem } \\
\text { Engineer }\end{array}$} & $\begin{array}{l}\text { Spartina alterniflora (smooth } \\
\text { cordgrass) }\end{array}$ & $\begin{array}{l}\text { Converts mudflats; reduces shorebird } \\
\text { foraging }\end{array}$ & $\begin{array}{l}\text { Neira et al. 2005, 2006, 2007; Levin et al. 2006; Tyle } \\
\text { et al. } 2007\end{array}$ \\
\hline & $\begin{array}{l}\text { Zostera japonica (Japanese } \\
\text { eelgrass) }\end{array}$ & Converts mudflats & Posey 1988 \\
\hline & $\begin{array}{l}\text { Crassostrea gigas (commercial } \\
\text { oyster) }\end{array}$ & Creates reefs & Ruesink et al. 2005 \\
\hline & $\begin{array}{l}\text { Musculista senhousia (Asian } \\
\text { mussel) }\end{array}$ & Creates byssal mats in sediments & Crooks \& Khim 1999 \\
\hline
\end{tabular}

clear when California and the USA tried to regulate Caulerpa species, and the consequence is that very few marine invasive species are regulated. Trait-based approaches are promising because previous invasion history elsewhere in the world is one of the most reliable ways to predict future problems (Hayes and Sliwa 2003; Kolar and Lodge 2002; Marchetti et al. 2004). Taxa with a higher than average propensity for successful establishment in nonnative habitats can be pinpointed (Daehler 1998; Lockwood 1999; Williams and Smith 2007). However, trait-based prevention approaches will require some refinement to be effective for marine species. For example, Wonham et al. (2000) found few biological correlates among 24 fish invasions linked to ballast water.

Another approach to screening undesirable species is based on the assumption that introductions will be most successful in habitats that closely match the characteristics of the donor environment. These matching approaches are variously referred to as 'environmental', 'niche', 'climate', and 'species distribution modeling (SDM)'. They all rely on multivariate analyses of the physiological tolerances and abiotic factors that set the range limits for a species, complemented by Geographic Information Systems (GIS; McKenney et al. 2003; Peterson 2003; Thuiller et al. 2005); they are also used to predict biogeographic ranges under climate change scenarios. These approaches are the backbone to screening plants in Australia (Australian Quarantine and Inspection Service 2003). The approach has not been applied much to marine species and will require an improved understanding of the abiotic factors that promote recruitment and population increase and more detailed marine GIS (Breman 2002) to be successful. Because the algorithms run quickly once the data are available, many species could be tackled in a short time. The approach could be refined by including ecological interactions that limit distributions of species. All approaches have limitations but, as described in studies from Australia and New Zealand cited above, there is no need to stall on preventing introductions while attempting to perfect the approach.

Early Detection Until prevention becomes a matter of policy, one can only hope to detect new introductions early enough to eradicate them. One of the most pressing needs for both research and management is rapid identification of introduced species (Campbell et al. 2007). New methods are being developed to detect stages of introduced species not readily identified by morphology (eggs, larvae, spores, etc.), but much more work is needed in this regard (Pradillon et al. 2007). Several new methods including genetic dipsticks, barcoding (Armstrong and Ball 2005), and shotgun sequencing are now in development for sampling water column stages. There is much discussion of the merits of these approaches with respect to identifying 'species' (Darling 2006; Fitzhugh 2006), and the resolution for some of these methods still needs improvement. One of the biggest limitations is the availability of sequence data in GenBank, which is quite sparse for many taxa. Nonetheless, Australia is using genetic probes to detect invasive marine and estuarine species (Hayes et al. 2005).

Risk Assessment The probability that a species will establish successfully multiplied by the probability that it will 
cause harm constitute the risk that managers need to know to prioritize and initiate their actions. All of the research needs discussed above fold into formal risk assessments, and the lack of data in many cases explains why there have been so few formal risk analyses for coastal and estuarine species (Bax et al. 2001; Floerl et al. 2005). Canada's Centre of Expertise for Aquatic Risk Assessment is advancing risk assessment by standardizing risk assessments for fisheries and invasive species (Canadian Government 2003). Their draft assessments are based on including extensive biological information, which they intend to acquire, and include genetic and disease impacts along with ecological risks. They also consider the impact of any hitchhiking nonnative species.

Understanding Connectivity to Prioritize Eradication and Control Efforts In absence of effective prevention and rapid detection, managers need a means to prioritize which introduced species to eradicate and control. One critical factor that could diminish the effectiveness of eradication and control programs for marine species is high connectivity among different populations. Introduced species characterized by widespread and open populations, connected by the rapid dispersal of propagules, can recolonize more rapidly than relatively isolated populations with lower connectivity. Species with highly connected populations thus will be more difficult to eradicate or control (Fig. 4). Despite this evident conclusion, scientists and managers lack a fundamental understanding of the connectivity among populations of marine species (Kinlan and Gaines 2003; Levin 2006). Such knowledge will help prioritize which species to manage. It will also support the applica-

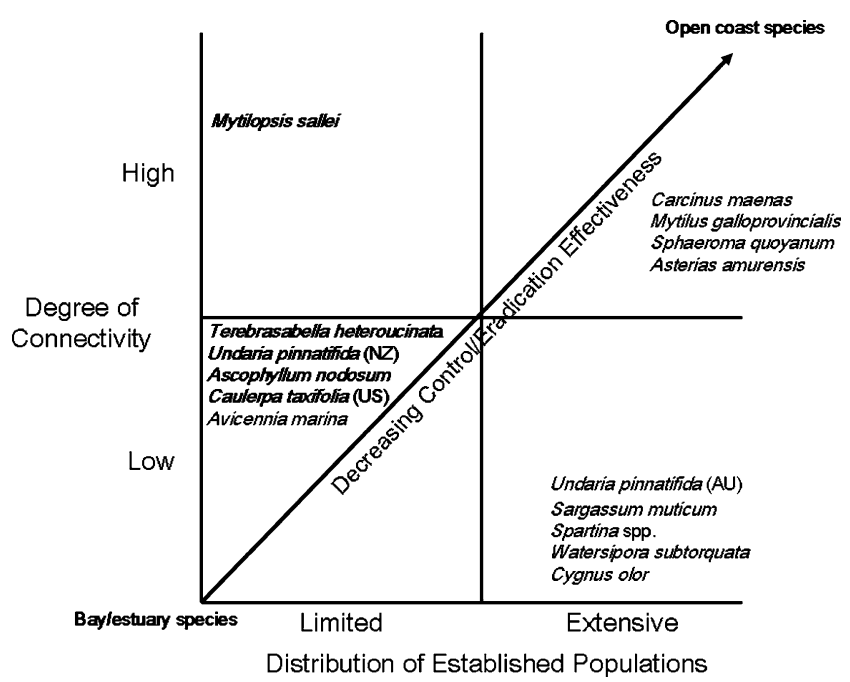

Fig. 4 Conceptual relationship between connectivity (natural dispersal) and expanse of populations of introduced species and the probability of successful management. Species in bold have been successfully eradicated tion of models, which depend on identifying dispersal 'kernels', to predict the spread of invasive species (Neubert and Caswell 2000). Promising technology (elemental fingerprinting) is being developed to quantify connectivity among marine populations of species that secrete hard parts (otoliths, shells, carapaces; DiBacco and Levin 2000; Becker et al. 2007).

Eradication and Control Needs Managers need an arsenal of tested techniques for eradication and control. Ideally, the methodology would not harm native species. Biocontrol theoretically could achieve this end, but the few natural enemies of introduced marine and estuarine species investigated to date have not proven sufficiently selective to function as biocontrol agents (Lafferty and Kuris 1996; Trowbridge and Todd 2001; Secord 2003). In Willapa Bay, Washington, however, a trial program was initiated in 2000 to control Spartina alterniflora using the planthopper, Prokelisia marginata, with promising early results (Grevstad et al. 2003). Transgenic approaches to controlling the reproduction of introduced marine species are also receiving research attention (Bax et al. 2006). The salty equivalent of a pheromone control, which has proven effective for many insect pests of agricultural crops (Arn 1990), awaits discovery. Disruption of molting or development in invasive crustaceans through molting hormones might be promising, but so far all species examined respond to the same hormones (E. Chang, personal communication).

A special challenge for mitigating undesirable effects of estuarine and coastal introduced species is the open and fluid nature of the ocean. Rapid dilution of pesticides in flowing waters reduces exposure to the pest, while increasing exposure to sensitive native species, and adequate containment structures are difficult and expensive to engineer. Nevertheless, the eradications of Mytilopsis sallei and Caulerpa taxifolia circumvented these challenges (Table 2).

The Need for Decision Support A pressing need expressed by both scientists and managers is a single source, readily accessible, step-wise management decision support system. When confronted with a potential new introduction, scientists and certainly managers cannot be expected to sift through scientific journals or individual websites. They need to identify the species and then proceed along a decision analysis pathway to options for response, identification of authorities and required regulations and permits, access to experts along the way, and an archive to support decision audits. Obviously, the system would be useful only as long as resources are available for its maintenance, but its costs could be shared across many users. Major developments in informatics place this kind of decision support system in reach (Ricciardi et al. 2000; Simpson 
et al. 2006), although lack of appropriate data is still an obstacle. Prototypes are in use (Wittenberg and Cock 2001), including NIMPIS, which was developed in part to memorialize the lessons learned from the eradication of the black striped mussel in Australia (Hewitt et al. 2002).

Evolutionary Potential An area that remains poorly investigated is the degree to which short-term or rapid evolution influences the success or failure of introduced species. The practical side to this research question is that certain tools used to screen potentially invasive species (see species distribution matching methods above) are based on the assumption that rapid adaptation to the new environment does not occur. Furthermore, managers of long-term invasions have noted changes in the biology of the introduced species (M. Wecker, personal communication). High levels of genetic variation within populations of introduced species (Roman 2006; Roman and Darling 2007; Lavergne and Molofsky 2007) can provide the opportunity for rapid evolution and adaptation to the new environment of the introduced range. Distinct introduction events can result in higher genetic diversity overall. On the other hand, species with low genetic diversity could also acclimate to new conditions by being phenotypically plastic (Dybdahl and Kane 2005). It is important to understand how the population genetic structure influences the likelihood that an introduced species will become a management problem.

Ecological Economics and Introduced Species Crossdisciplinary approaches are also needed to understand the importance of the impacts of introduced species, which bears directly on how managers will respond to a given species. Ecologists and economists have begun to formally address the costs of introduced species (Leung et al. 2005; Finnoff et al. 2007) and to develop better recommendations for invasive species management (Buhle et al. 2005). However, there are few data available for most species with which to either conduct a formal risk analysis or to develop damage functions for use in traditional economic models (Lovell et al. 2007).

The following research needs are ones that have practical implications for management but are not widely recognized in the management community.

Facilitation of Subsequent Introduced Species To understand the impacts of invasive species, it is critical to consider how an introduced species can influence subsequent introductions. Some introduced species can facilitate subsequent invasions and knowing which species are likely to be "facilitators" can provide critical information for management efforts. In cases where facilitation occurs, the need for preemptive management strategies is even greater. Although there have been discussions of potential mechanisms (Simberloff and Von Holle 1999; Rodriguez 2006), there are only a handful of documented examples in marine systems (Levin et al. 2002; Floerl et al. 2004; Grosholz 2005; Wonham et al. 2005). In some cases, new invasive species can facilitate and accelerate the invasion of species introduced many years earlier turning them into new management headaches (Grosholz 2005). It however is unknown whether facilitative interactions such as these occur more commonly among invasive species than among native species, although the same types of approaches are available.

Climate Change and Species Introductions Finally, understanding how climate change interacts with coastal invasions will be critical for understanding and predicting successful invasions as well as managing their impacts. The recent Intergovernmental Panel on Climate Change (IPCC) makes it clear that many factors including increasing sea-surface temperatures, rising sea levels, increasing atmospheric $\mathrm{CO}_{2}$ and ocean acidification will significantly impact coastal habitats in the coming decades (Bindoff et al. 2007). Temperature increases alone can lead to the increased success of introduced species (Stachowicz et al. 2002). Rising sea-levels pose a significant risk for coastal estuaries, particularly ones with armored boundaries that prevent migrations as tides creep up. Given a eustatic sea level rise of nearly $3 \mathrm{~mm} /$ year (Bindoff et al. 2007; Stevenson and Kearney 2007), tidal marshes will become increasingly inundated with largely unknown consequences for species invasions. For example, changes in tidal height of a few centimeters can determine whether mudflats invaded by Spartina will transition to either a vegetated high marsh state, the original open mudflat (SFB), or will be colonized by invasive Zostera japonica (Grosholz et al. in press). Tidal inundation coupled with the lack of sediment deposition has also been implicated in the stresses faced by tidal marshes in the Gulf of Mexico (Mendelssohn and Kuhn 2003).

Elevated $\mathrm{CO}_{2}$ levels are also likely to play a role in altering the success of introduced species. Long-term experimental studies have shown that invasive $\mathrm{C}_{3}$ plants are likely to benefit from increased $\mathrm{CO}_{2}$ levels in complicated ways (Curtis et al. 1989; Marsh et al. 2005; Rasse et al. 2005). Finally, ocean acidification under increasing $\mathrm{CO}_{2}$ concentrations could make communities of bivalves and coral reefs less resistant to introduced species that do not calcify (e.g., ascidians). In estuaries, which are less well buffered than the open ocean, the effect of increasing $\mathrm{CO}_{2}$ partial pressures on the carbonate equilibrium will be site specific. Thus, it will be more difficult to predict the effects on calcification processes. 
The overarching challenge will be figuring out how the suite of climate change effects on individual species will scale up to marine communities. Few studies have addressed factors in addition to rising temperatures (e.g., Erickson et al. 2007), let alone effects on introduced species (Braby and Somero 2006; Schneider and Helmuth 2007). The complexity of ecological interactions will necessitate sophisticated ecological forecasting (Helmuth et al. 2006). On the policy side, there is a danger that as species shift their distributions in response to climate change, the distinction between species introduced by humans and the others will blur (Rocha et al. 2007; Perry et al. 2007), to the detriment of preventing and managing new introductions. After the IPCC's compelling 2007 report, some of the attention on invasive species management has been diverted. However, it is important that we not lose sight of the rapid acceleration of observed invasions and the fact that invasions have significant impacts and will interact with other anthropogenic changes. To balance the perspective, the changes in the distributions of species over the past 200-500 years due to human activities have rivaled those during ice ages (di Castri 1989).

\section{Summary}

The overall situation in estuaries and on coasts is one of great and interrelated anthropogenic changes. The establishment of nonnative species is likely to increase as the ocean warms (Stachowicz et al. 2002) and as eutrophication-related hypoxia increases (Jewett et al. 2005) and the vectors that distribute them proliferate. The challenge for scientists and managers is to determine how multiple perturbations to these environments interact, and which ones can be managed effectively. Management of introduced species requires the same will and resources that nations have applied to reducing pollution and restoring wetlands and fisheries stocks, with high pay-offs, and investments spent on restoration efforts risk being obliterated by the introduction of just one successful nonnative species.

Thanks to the rapid scientific advances that offer new tools for managers, the time has never been better to halt the increasing number and costs of introduced species in estuaries and on coasts. Australia and New Zealand have demonstrated that research and management can be effectively integrated. Canada is developing risk assessments that require extensive biological information. European nations have grappled with managing introductions from their extensive aquaculture (Gollasch 2007). Introduced species have been on the scientific and management radar globally for a relatively short time, compared to species extinctions, pollution, and habitat destruction. Their effects have come to light faster than those associated with global warming. Unlike the daunting challenge of mitigating global climate change, the solutions to the problem of invasive species are known and well within reach. It is not rocket science: the vectors and high-priority species have been identified, and good institutional models are already working. In particular, the management emphasis in most countries must shift from costly eradication and control programs to proactive prevention, following the leads by Australia and New Zealand.

Acknowledgment We thank Carlos Duarte for inviting this perspective. We owe many colleagues and managers over the years for sharpening our perspective. N. Bax constructively reviewed the manuscript and provided valuable information. J. Carlton reviewed the eradication project examples and provided a few more. The following busy managers responded to our queries about eradication and science: S. Ellis, I. Kay, J. Mello, J. Moore, B. Posthumus, S. Scholosser, M. Wecker. We thank SCCAT team members and our 'connectivity colleagues' (A. Kuris, L. Levin, S. Morgan). G. Ruiz and A. Chang commented on the manuscript. M. Engelbrecht (Cadet Hand Librarian, Bodega Marine Laboratory) provided the data for Fig. 1.

\section{References}

Alpine, A.E., and J.E. Cloern. 1992. Trophic interactions and direct physical effects control phytoplankton biomass and production in an estuary. Limnology and Oceanography 37: 946-955.

Anderson, L.W.J. 2005. California's reaction to Caulerpa taxifolia: A model for invasive species rapid response. Biological Invasions 7: 1003-1016.

Anderson, L.W.J., W.L. Tan, R. Woodfield, R. Mooney, and K. Merkel. 2005. Use of sediment bioassays to verify efficacy of Caulerpa taxifolia eradication treatments. Journal of Aquatic Plant Management 43: 1-9.

Aquatic Nuisance Species Task Force. 2003. National Management Plan for the Genus Eriocheir (Mitten Crabs). Arlington, Virginia: US Fish and Wildlife Service.

Armstrong, K.F., and S.L. Ball. 2005. DNA barcodes for biosecurity: invasive species identification. Philosophical Transactions of the Royal Society B: Biological Sciences 360: 1813-1823.

Arn, H. 1990. Pheromones: prophesies, economics, and the ground swell. In Behavior-modifying chemicals for insect management, eds. R. L. Ridgway, , R. M. Silverstein, and M. N. Inscoe, $717-$ 722. New York, New York, USA: Marcel Dekker.

Ayres, D.R., D.R. Smith, D.L. Zaremba, K. Klohr, and D.R. Strong. 2004. Spread of exotic cordgrasses and hybrids (Spartina sp.) in the tidal marshes of San Francisco Bay, California, USA. Biological Invasions 6: 221-231.

Bax, N., P. Dunstan, R. Gunasekera, J. Patil, and C. Sutton. 2006. Evaluation of national control plan management options for the northern Pacific seastar Asterias amurensis. Final Project Report 46629 to the Natural Heritage Trust, Australian Government, Canberra, Australia.

Bax, N.J., and F.R. McEnnulty. 2001. Rapid response options for managing marine pest incursions. Final Report for NHT/C\&CS project 21249 to the National Heritage Trust, Introduced Marine Pests Program. CSIRO, Hobart, Tasmania, Australia.

Bax, N., K. Hayes, A. Marshall, D. Parry, and R. Thresher. 2002. Man-made marinas as sheltered islands for alien marine 
organisms: establishment and eradication of an alien invasive marine species. In: Turning the Tide: The Eradication of Invasive Species, IUCN SSC Invasive Species Specialist Group, IUCN, eds. Veitch, C. R., and M. N. Clout, 26-39. Gland, Switzerland.

Bax, N., J.T. Carlton, A. Mathews-Amos, R.L. Haedrich, F.G. Howarth, J.E. Purcel, A. Rieser, and A. Gray. 2001. The control of biological invasions in the world's oceans. Conservation Biology 15: 1234-1246.

Becker, B.J., L.A. Levin, F.J. Fodrie, and P.A. McMillan. 2007. Complex larval connectivity patterns among marine invertebrate populations. Proceedings of the National Academy of Sciences 104: 3267-3272.

Bindoff, N.L., J. Willebrand, V. Artale, A. Cazenave, J. Gregory, S. Gulev, K. Hanawa, C.L. Quere, S. Levitus, Y. Nojiri, C.K. Shum, L. Talley, and A. Unnikrishnan. 2007. Observations: oceanic climate change. In Climate Change 2007: The Physical Science Basis. Contribution of Working Group I to the Fourth Assessment Report of the Intergovernmental Panel of Climate Change, eds. S. Solomon, D. Qin, M. R. Manning, Z. Chen, M. Marquis, K. B. Avery et al Cambridge, Great Britain: Cambridge University Press.

Blossey, B. 1999. Before, during and after: the need for long-term monitoring in invasive plant species management. Biological Invasions 1: 301-311.

Braby, C.E., and G.N. Somero. 2006. Following the heart: temperature and salinity effects on heart rate in native and invasive species of blue mussels (genus Mytilus). Journal of Experimental Biology 209: 255-2566.

Breman, J. 2002. Marine geography: GIS for the Oceans and Seas. Redlands, California, USA: ESRI Press.

Brown, J.J., R. Hildreth, and S.E. Ford. 2005. When the world is not your oyster. Science 309: 244.

Brusati, E.D., and E.D. Grosholz. 2006. Native and introduced ecosystem engineers produce contrasting effects on estuarine infaunal communities. Biological Invasions 8: 683-695.

Brusati, E.D., and E.D. Grosholz. 2007. Effect of native and invasive cordgrass on Macoma petalum density, growth and isotopic signatures. Estuarine Coastal and Shelf Science 71: 517-522.

Buhle, E.R., M. Margolis, and J.L. Ruesink. 2005. Bang for buck: cost-effective control of invasive species wih different life histories. Ecological Economics 52: 355-366.

California Coastal Conservancy. 2007. Invasive Spartina Project (ISP). Phase II-Control Program, 2007 Implementation of Control Program. Oakland, California, USA.

Campbell, M.L., B. Gould, and C.L. Hewitt. 2007. Survey evaluations to assess marine bioinvasions. Marine Pollution Bulletin 55: $360-378$

Canadian Government. 2003. National code on introductions and transfers of aquatic organisms.

Carlton, J.T. 2001. Introduced species in U.S. coastal waters: environmental impacts and management priorities. Arlington, Virginia: Pew Oceans Commission Report.

Carlton, J.T., and J.B. Geller. 1993. Ecological roulette: the global transport of non-indigenous marine organisms. Science 261: 7882.

Ceccherelli, G., and F. Cinelli. 1997. Short-term effects of nutrient enrichment of the sediment and interactions between the seagrass Cymodocea nodosa and the introduced green alga Caulerpa taxifolia in a Mediterranean bay. Journal of Experimental Marine Biology and Ecology 217: 165-177.

Ceccherelli, G., and D. Campo. 2002. Different effects of Caulerpa racemosa on two co-occurring seagrasses in the Mediterranean. Botanica Marina 45: 71-76.

Chapman, J.W., T.W. Miller, and E.V. Coan. 2003. Live seafood species as recipes for invasion. Conservation Biology 17: 1386-1395.

Cheshire, A., G. Westphalen, V. Boxall, R. Marsh, J. Gilliland, G. Collings, S. Seddon, and M. Loo. 2002. Caulerpa taxifolia in
West Lakes and the Port River, South Australia: distribution, eradication options and consequences. A report to the PIRSA Fisheries, Marine Habitat Program. SARDI Aquatic Science Publication \#RD02/0161. South Australia Research and Development Institute, Aquatic Science, Hentley Beach, South Australia.

Civille, J.C., K. Sayce, S.D. Smith, and D.R. Strong. 2005. Reconstructing a century of Spartina alterniflora invasion with historical records and contemporary remote sensing. Ecoscience 12: $330-338$.

Cohen, A.N., and J.T. Carlton. 1995. Nonindigenous aquatic species in a United States estuary: a case study of the biological invasions of the San Francisco Bay and Delta. Arlington, Virginia, USA: U.S. Fish and Wildlife Service.

Colautti, R.I., S.A. Bailey, C.D.A. van Overdijk, K. Amundsen, and H.J. MacIsaac. 2006. Characterised and projected costs of nonindigenous species in Canada. Biological Invasions 8: 45-59.

Collings, G., G. Westphalen, A. Cheshire, K. Rowling, and M. Theil. 2004. Caulerpa taxifolia (Vahl) C. Agardh eradication efforts in West Lakes, South Australia. SARDI Aquatic Sciences Publication RD02/0161-8. South Australia Research and Development Institute, Aquatic Science, Hentley Beach, South Australia.

Coordinating Group for Alien Pest Species and other Hawaiian agencies. 2006. Island-based partnerships \& statewide coordination to protect Hawaii from invasive species. Report for the 2006 calendar year. Honolulu, Hawai'i.

Council of Europe. 2004. European strategy on invasive alien species. Nature and Environment 137: 1-67.

Coutts, A.D.M., and B.M. Forrest. 2007. Development and application of tools for incursion response: lessons learned from the management of the fouling pest Didemnum vexillum. Journal of Experimental Marine Biology and Ecology 342: 154-162.

Crooks, J.A. 2002. Characterizing ecosystem-level consequences of biological invasions: the role of ecosystem engineers. Oikos 97: $153-166$.

Crooks, J.A. 2005. Lag times and exotic species: the ecology and management of biological invasions in slow motion. Ecoscience 12: 316-329.

Crooks, J.A., and H.S. Khim. 1999. Architectural vs. biological effects of a habitat-altering, exotic mussel, Musculista senhousia. Journal of Experimental Marine Biology and Ecology 240: 5375.

Culver, C.S., and A.M. Kuris. 2000. The apparent eradication of a locally established introduced marine pest. Biological Invasions 2: 245-253.

Curtis, P.S., B.G. Drake, and D.F. Whigham. 1989. Nitrogen and carbon dynamics in $\mathrm{C}_{3}$ and $\mathrm{C}_{4}$ estuarine marsh plants grown under elevated $\mathrm{CO}_{2}$ in situ. Oecologia 78: 297-301.

Daehler, C.C. 1998. The taxonomic distribution of invasive angiosperm plants: Ecological insights and comparison to agricultural weeds. Biological Conservation 84: 167-180.

Daehler, C.C., and D.R. Strong. 1997. Hybridization between introduced smooth cordgrass (Spartina alterniflora; Poaceae) and native California cordgrass (S. foliosa) in San Francisco Bay, California, USA. American Journal of Botany 84: 607-611.

Dalton, R. 2000. Researchers criticize response to killer algae. Nature 406: 447.

Dalton, R. 2001. Action urged to combat killer algae. Nature 412: 260.

Darling, J. 2006. The value of barcoding. BioScience 56: 710-711.

Davis, H.G., C.M. Taylor, J.C. Civille, and D.R. Strong. 2004. An Allee effect at the front of a plant invasion: Spartina in a Pacific estuary. Journal of Ecology 92: 321-327.

Davis, E.R., K. Benkwndorff, and D.W. Ward. 2005. Responses of common SE Australian herbivores to three suspected invasive Caulerpa spp. Marine Biology 146: 859-868. 
Defenders of Wildlife. 2007. Broken Screens: The Regulation of Live Animal Imports in the United States. Washington, District of Columbia.

di Castri, F. 1989. History of biological invasions with emphasis on the Old World. In Biological Invasions: A Global Perspective, eds. J. Drake, , F. di Castro, R. Groves, F. Kruger, H. A. Mooney, M. Rejmanek, and M. Williamson, 1-30. New York, New York, USA: Wiley.

DiBacco, C., and L.A. Levin. 2000. Development and application of elemental fingerprinting to track the dispersal of marine invertebrate larvae. Limnology and Oceanography 45: 871880 .

Dommisse, M., and D. Hough. 2004. Controlling the Northern Pacific Seastar (Asteria amurensis) in Australia. Final Report, Australian Government Department of the Environment and Heritage. State of Victoria, Department of Sustainability and Environment.

Dybdahl, M.F., and S.L. Kane. 2005. Adaptation vs. phenotypic plasticity in the success of a clonal invader. Ecology 86: 15921601.

Eicher, A. 2006. Humboldt Bay Harbor, Recreation and Conservation District Permit No. 03-03, Annual Report: 2006. Humboldt Bay Cooperative Eelgrass Project, Eureka, California, USA.

Eno, C.N., R.A. Clark, and W. Sanderson (eds). 1997. Non-native Marine Species in British Waters: A Review and Directory. Joint Nature Conservancy Committee, Petersborough, United Kingdom.

Erickson, J.E., J.P. Megonigal, G. Peresta, and B.G. Duke. 2007. Salinity and sea level mediate elevated $\mathrm{CO}_{2}$ effects on C3-C4 plant interactions and tissue nitrogen in a Chesapeake Bay tidal wetland. Global Change Biology 13: 202-215.

Feist, B.E., and C.A. Simenstad. 2000. Expansion rates and recruitment frequency of exotic smooth cordgrass, Spartina alterniflora (Loisel), colonizing unvegetated littoral flats in Willapa Bay, Washington. Estuaries 23: 267-274.

Ferguson, R. 2000. The effectiveness of Australia's response to the black striped mussel incursion in Darwin, Australia. A report of the Marine Pest Incursion Management Workshop, 1999. Canberra, Australia: Department of Environment and Heritage.

Finnoff, D., J.F. Shogren, B. Leung, and D. Lodge. 2007. Take a risk: preferring prevention over control of biological invaders. Ecological Economics 62: 216-222.

Fitzhugh, K. 2006. DNA barcoding: an instance of technology-driven science? BioScience 56: 462-463.

Floerl, O., T.K. Pool, and G.J. Inglis. 2004. Positive interactions between nonindigenous species facilitate transport by human vectors. Ecological Applications 14: 1724-1736.

Floerl, O., G.J. Inglis, and B.J. Hayden. 2005. A risk-based predictive tool to prevent accidental introductions of nonindigenous marine species. Environmental Management 35: 765-778.

Galil, B.S. 2007. Loss or gain? Invasive aliens and biodiversity in the Mediterranean Sea. Marine Pollution Bulletin 55: 314-322.

Genovesi, P. 2005. Eradications of invasive alien species in Europe: a review. Biological Invasions 7: 127-133.

Glasby, T.M., R.G. Creese, and P.T. Gibson. 2005. Experimental use of salt to control the invasive marine alga Caulerpa taxifolia in New South Wales, Australia. Biological Conservation 122: 573580 .

Gollan, J.R., and J.T. Wright. 2006. Limited grazing pressure by native herbivores on the invasive seaweed Caulerpa taxifolia in a temperate Australian estuary. Marine and Freshwater Research 57: 685-694.

Gollasch, S. 2007. International collaboration on marine bioinvasionsthe ICES response. Marine Pollution Bulletin 55: 353-359.

Graham, W.M., D.L. Martin, D.L. Felder, V.L. Asper, and H.M. Perry. 2003. Ecological and economic implications of a tropical jellyfish invader in the Gulf of Mexico. Biological Invasions 5: 53-69.
Grevstad, F.S., D.R. Strong, D. Garcia-Rossi, R.W. Switzer, and W.S. Wecker. 2003. Biological control of Spartina alterniflora in Willapa Bay, Washington using the plantopper Prokelisia marginata: agent specificity and early results. Biological Control 27: $32-42$.

Gribben, P.E., and J.T. Wright. 2006a. Invasive seaweed enhances recruitment of a native bivalve: roles of refuge from predation and the habitat choice of recruits. Marine Ecology Progress Series 318: 177-185.

Gribben, P.E., and J.T. Wright. 2006b. Sublethal effects on reproduction in native fauna: are females more vulnerable to biological invasion? Oecologia 149: 352-361.

Grosholz, E. 2002. Ecological and evolutionary consequences of coastal invasions. Trends in Ecology and Evolution 17: 22-27.

Grosholz, E.D. 2005. Recent biological invasion may hasten invasional meltdown by accelerating historical introductions. Proceedings of the National Academy of Sciences 102: 1088-1091.

Grosholz, E.D., G.M. Ruiz, C.A. Dean, K.A. Shirley, J.L. Maron, and P.G. Connors. 2000. The impacts of a non-indigenous predator in a California bay. Ecology 81: 1206-1224.

Grosholz, E.D., P.G. Olin, B. Williams, and R. Tinsman. 2001. Reducing predation on Manila clams by nonindigenous European green crabs. Journal of Shellfish Research 20: 913-919.

Grosholz, E.D., L.A. Levin, A.C. Tyler, and C. Neira (in press). Changes in community structure and ecosystem function following Spartina alterniflora invasion of Pacific estuaries. In Silliman, B. R., M. D. Bertness and E. D. Grosholz (eds.). Anthropogenic Modification of North America Salt Marshes. University of California, Berkeley, California, USA.

Grosholz, E.D., and G.M. Ruiz. (in press). Multitrophic effects of invasions in marine and estuarine systems. In Rilov, G. and J. Crooks (eds), Marine Bioinvasions: Ecology, Conservation and Management Perspectives. Springer-Verlag, New York, New York.

Hallegraeff, G.M. 1998. Transport of toxic dinoflagellates via ships' ballast water: bioeconomic risk assessment and efficacy of possible ballast water management strategies. Marine Ecology Progress Series 168: 297-309.

Hammond, M.E.R., and A. Cooper. 2002. Spartina anglica eradication and inter-tidal recovery in Northern Ireland estuaries. p. 124-131. In C. R. Veitch and M. N. Clout (eds.), Turning the Tide: the Eradication of Invasive Species. IUCN SSC Invasive Species Specialist Group. IUCN, Gland Switzerland.

Hayes, K.R. 2003. Biosecurity and the role of risk-assessment. In Bioinvasions: pathways, vectors, and management strategies, eds. G. M. Ruiz, , and J. T. Carlton, 227-246. New York, New York, USA: Island Press.

Hayes, K.R., R. Cannon, K. Neil, and G. Inglis. 2005. Sensitivity and cost considerations for the detection and eradication of marine pests in ports. Marine Pollution Bulletin 50: 823-834.

Hayes, K.R., and C. Sliwa. 2003. Identifying potential marine pests- a deductive approach applied to Australia. Marine Pollution Bulletin 46: 91-98.

Helmuth, B.N., P. Mieszkowska, P. Moore, and S.J. Hawkins. 2006. Living on the edge of two changing worlds: forecasting the responses of rocky intertidal ecosystems to climate change. Annual Review of Ecology, Evolution, and Systematics 37: 373404.

Hewitt, C.L., and M.L. Campbell. 2007. Mechanisms for the prevention of marine bioinvasions for better biosecurity. Marine Pollution Bulletin 55: 395-401.

Hewitt, C.L., M.L. Campbell, F. McEnnulty, K.M. Moore, N.B. Murfet, B. Robertson, and B. Schaffelke. 2005. Efficacy of physical removal of a marine pest: the introduced kelp Undaria pinnatifida in a Tasmanian Marine Reserve. Biological Invasions 7: 251-263. 
Hewitt, C.L., R.B. Martin, C. Sliwa, F.R. McEnnulty, N.E. Murphy, T. Jones, and S. Cooper. 2002. National Introduced Marine Pest Information System. Commonwealth Scientific and Industrial Research Organization, http://crimp.marine.csiro.au/nimpis (date of access: 13-Sept.-2007).

International Council for the Exploration of the Sea. 2005. Code of Practice on the Introductions and Transfers of Marine Organisms. Copenhagen, Denmark.

Jenkins, P.T. 1996. Free trade and exotic species introductions. Conservation Biology 10: 300-302.

Jewett, E.B., A.H. Hines, and G.M. Ruiz. 2005. Epifaunal disturbance by periodic low levels of dissolved oxygen: native vs. invasive species responses. Marine Ecology Progress Series 304: 31-44.

Jousson, O., J. Pawlowski, L. Zaninetti, A. Meinesz, and C.F. Boudouresque. 1998. Molecular evidence for the aquarium origin of the green alga Caulerpa taxifolia introduced to the Mediterranean Sea. Marine Ecology Progress Series 172: 275-280.

Kappel, C.V. 2005. Losing pieces of the puzzle: threats to marine, estuarine, and diadromous species. Frontiers in Ecology and the Environment 3: 275-282.

Kay, I., A. Demopoulos, and L. Levin. 2006. Resurrection: a case study of introduced mangroves re-infesting the Mission Bay Marsh, San Diego, California. Ecological Society of America, Annual Meeting, Abstract.

Kerr, R.A. 2006. A worrying trend of less ice, higher seas. Science 311: 1698-1701.

Kimmerer, W.J., E. Gartside, and J.J. Orsi. 1994. Predation by an introduced clam as the likely cause of substantial declines in zooplankton of San Francisco Bay. Marine Ecology Progress Series 113: 81-93.

Kinlan, B.P., and S.D. Gaines. 2003. Propagule dispersal in marine and terrestrial environments: a community perspective. Ecology 84: 2007-2020.

Kolar, C.S., and D.M. Lodge. 2002. Ecological predictions and risk assessment for alien fishes in North America. Science 298: 12331236.

Krikwoken, L.K., and P. Hedge. 2000. Exotic species and estuaries: managing Spartina anglica in Tasmania, Australia. Ocean Coast. Manage43:573-584.

Kuris, A. 2003. Eradication of introduced pests. In Managing for healthy ecosystems, eds. D. J. Rapport, , B. L. Lasley, D. E. Rolston, N. O. Nielsen, C. O. Qualset, and A. B. Damania. New York, New York: Lewis Publishers.

Lafferty, K.D., and A.M. Kuris. 1996. Biological control of marine pests. Ecology 77: 1989-2000.

Larned, S.T. 2003. Effects of the invasive, nonindigenous seagrass Zostera japonica on nutrient fluxes between the water column and benthos in a NE Pacific estuary. Marine Ecology Progress Series 254: 69-80.

Lavergne, S., and J. Molofsky. 2007. Increased genetic variation and evolutionary potential drive the success of an invasive grass. Proceedings of the National Academy of Sciences 104: 3883-3888.

Leung, B., D. Finnoff, J.F. Shogren, and D. Lodge. 2005. Managing invasive species: rules of thumb for rapid assessment. Ecological Economics 55: 24-36.

Levin, L.A. 2006. Recent progress in understanding larval dispersal: new directions and digressions. Integrative and Comparative Biology 46: 282-297.

Levin, P.S., J.A. Coyer, R. Petrik, and T.P. Good. 2002. Communitywide effects of nonindigenous species on temperate rocky reefs. Ecology 83: 3182-3193.

Levin, L.A., C. Neira, and E.D. Grosholz. 2006. Invasive cordgrass modifies wetland trophic function. Ecology 87: 419-432.

Lockwood, J.L. 1999. Using taxonomy to predict success among introduced avifauna: Relative importance of transport and establishment. Conservation Biology 13: 560-567.
Lodge, D.M., S. Williams, H. MacIsaac, K. Hayes, B. Leung, S. Reichard, R.N. Mack, M.S.P.B. Moyle, D.A. Andow, J.T. Carlton, and A. McMichael. 2006. Biological invasions: recommendations for U.S. policy and management. Ecological Applications 16: 2035-2054.

Lonhart, S. 2003. Status of the invasive algal Undaria pinnifida in Monterey Harbor. http://montereybay.noaa.gov/research/techreports/ undariawsn.html (accessed 15 December 2007).

Lowe, S., M. Browne, S. Boudjelas, and M.D. Pooner. 2004. 100 of the World's Worst Invasive Alien Species. The Invasive Species Specialist Group, International Union for the Conservation of Nature, University of Auckland, New Zealand.

Mack, R.N., D. Simberloff, W.M. Lonsdale, H. Evans, M. Clout, M. Clout, and F.A. Bazzaz. 2000. Biotic invasions: Causes, epidemiology, global consequences, and control. Ecological Applications 10: 689-710.

Manchester, S., and J. Bullock. 2000. The impacts of non-native species on UK biodiversity and the effectiveness of control. Journal of Applied Ecology 37: 845-864.

Marchetti, M.P., P.B. Moyle, and R. Levine. 2004. Invasive species profiling: exploring characteristics of non-native fishes across invasion stages in California. Freshwater Biology 49: 646-661.

Margolis, M., J.F. Shogren, and C. Fischer. 2005. How trade politics affect invasive species control. Ecological Economics 52: 305 313.

Marsh, A.S., D.P. Rasse, B.G. Drake, and J.P. Megonigal. 2005. Effect of elevated $\mathrm{CO}_{2}$ on carbon pools and fluxes in a brackish marsh. Estuaries 28: 694-704.

McKenney, D.W., A.A. Hopkin, K.L. Campbell, B.G. Mackey, and R. Foottit. 2003. Opportunities for improved risk assessments of exotic species in Canada using bioclimatic modeling. Environmental Monitoring and Assessment 88: 445-461.

McNeely, J.A., L.E. Neville, and M. Rejmanek. 2003. When is eradication a sound investment? Strategically responding to invasive alien species. Conservation Magazine 4: 30-31.

Meinesz, A. 1999. Killer Algae. Chicago, Illinois, USA: University of Chicago.

Meinesz, A., T. Belsher, T. Thibaut, B. Antolic, K.B. Mustapha, C.-F. Boudouresque, D. Chiaverini, F. Cinelli, J.-M. Cottalorda, A. Djellouli, A. El Abed, C. Orestano, A.M. Grau, L. Ivesa, A. Jaklin, H. Langar, E. Massuti-Pascual, A. Peirano, L. Tunesi, J. de Vaugelas, N. Zavodnik, and A. Zuljevic. 2001. The introduced green alga Caulerpa taxifolia continues to spread in the Mediterranean. Biological Invasions 3: 201-210.

Mendelssohn, I.A., and N.L. Kuhn. 2003. Sediment subsidy: effects on soil-plant responses in a rapidly submerging coastal salt marsh. Ecological Engineering 21: 115-128.

Michener, W.K., E.R. Blood, K.L. Bildstein, M.M. Brinson, and L.R. Gardner. 1997. Climate change, hurricanes and tropical storms, and rising sea level in coastal wetlands. Ecological Applications 7: 770-801.

Miller, A.W., A.L. Chang, N. Cosentino-Manning, and G.M. Ruiz. 2004. A new record and eradication of the Northern Atlantic alga Ascophyllum nodosum (Phaeophyceae) from San Francisco Bay, California, USA. Journal of Phycology 40: 1028-1031.

Mitch, W.J., J.J.W. Day, W. Gilliam, P.M. Groffman, D.L. Hey, G.W. Randall, and N. Wang. 2001. Reducing nitrogen loading to the Gulf of Mexico from the Mississippi River Basin: strategies to counter a persistent ecological problem. BioScience 51: 373388.

Murphy, K.C., R.R. Taylor, and C.H. Phillips. 2007. Progress of the 2006 Spartina eradication program. Olympia, Washington, USA: Washington State Department of Agriculture.

Myers, J.H., D. Simberloff, A.M. Kuris, and J.R. Carey. 2000. Eradication revisited: dealing with exotic species. Trends in Ecology and Evolution 15: 316-320. 
National Invasive Species Council. 2001. Meeting the Invasive Species Challenge: Management Plan. Washington, District of Columbia, USA.

Naylor, R., S.L. Williams, and D.R. Strong. 2001. Aquaculture- a gateway for exotic species. Science 294: 1655-1656.

Neill, P.E., O. Alcalde, S. Faugeron, S.A. Navarrete, and J.A. Correa. 2006. Invasion of Codium fragile ssp. tomentosoides in northern Chile: a new threat for Gracilaria farming. Aquaculture 259: 202-210.

Neira, C., L. Levin, and E.D. Grosholz. 2005. Benthic macrofaunal communities of three Spartina-hybrid invaded sites in San Francisco Bay, with comparison to uninvaded sites. Marine Ecology Progress Series 292: 111-126.

Neira, C., E.D. Grosholz, L.A. Levin, and R. Blake. 2006. Mechanisms generating modification of benthos following tidal flat invasion by Spartina (alterniflora X foliosa). Ecological Applications 16: 1391-1404.

Neira, C., L.A. Levin, E.D. Grosholz, and G. Mendoza. 2007. Influence of invasive Spartina growth stages on associated macrofaunal communities. Biological Invasions: DOI 10.1007/ s10530-007-9097-x.

Neubert, M.G., and H. Caswell. 2000. Demography and dispersal: calculation and sensitivity analysis of invasion speed for structured populations. Ecology 81: 1613-1628.

Nicholls, R.J., and J.A. Lowe. 2004. Benefits of mitigation of climate change for coastal areas. Global Environmental Change-Human and Policy Dimensions 14: 229-244.

O'Connell, K.A. 2002. Effects of invasive Atlantic smooth cordgrass (Spartina alterniflora) on infaunal macroinvertebrate communities in southern Willapa Bay, WA. M. S. Thesis, Western Washington University, Bellingham, Washington, USA.

Olofson, P., E. Grijalva, I. Hogle, S. Erickson, and M. Spellman. 2007. Spartina dispatch. San Francisco Estuary Invasive Spartina Project, Berkeley, California, USA.

Padilla, D.K., and S.L. Williams. 2004. Beyond ballast water: aquarium and ornamental trades as sources of invasive species in aquatic ecosystems. Frontiers in Ecology and the Environment 2: 131-138.

Pauwelyn, J. 1999. The WTO agreement on sanitary and phytosanitary (SPS) measures, as applied in the first three SPS disputes: EC- hormones, Australia- salmon and Japan- varietals. Journal of International Economic Law 2: 641-664.

Perlman, D. 2000. Killer Algae' migrates to California coastMediterranean species found near San Diego. San Francisco, California, USA: San Francisco Chronicle.

Perry, A.L., P.J. Low, J.R. Ellis, and J.D. Reynolds. 2007. Climate change and distribution shifts in marine fishes. Science 308: 1912-1915.

Peterson, A.T. 2003. Predicting the geography of species' invasions via ecological niche modeling. The Quarterly Review of Biology 78: 419-433.

Pfauth, M., M. Systema, and D. Isaacson. 2003. Oregon Spartina Plan. Salem, Oregon: Oregon Department of Agriculture.

Posey, M.H. 1988. Community changes associated with the spread of an introduced seagrass, Zostera japonica. Ecology 69: 974-983.

Pradillon, F., A. Schmidt, J. Peplies, and N. Dubilier. 2007. Species identification of marine invertebrate early stages by whole-larvae in situ hybridisation of $18 \mathrm{~S}$ ribosomal RNA. Marine Ecology Progress Series 333: 103-116.

Rasse, D.P., G. Peresta, and B.G. Drake. 2005. Seventeen years of elevated $\mathrm{CO}_{2}$ exposure in a Chesapeake Bay wetland: sustained but contrasting responses of plant growth and $\mathrm{CO}_{2}$ uptake. Global Change Biology 11: 369-377.

Reise, K., S. Olenin, and D.W. Thieltges. 2006. Are aliens threatening European aquatic coastal ecosystems? Helgoland Marine Research 60: $77-83$.

Revkin, A.C. 2007. A moveable beast: Asian pythons thrive in Florida. New York, New York, USA: The New York Times.
Ricciardi, A., W.W. Steiner, R.N. Mack, and D. Simberloff. 2000. Toward a Global Information System for invasive species. BioScience 50: 239-244.

Richman, S.E., and J.R. Lovvorn. 2004. Relative foraging value to lesser scaup ducks of native and exotic clams from San Francisco Bay. Ecological Applications 14: 1217-1231.

Rocha, L.A., D.R. Robertson, C.R. Rocha, J.L. van Tassell, M.T. Craig, and B.W. Bowens. 2007. Recent invasion of the tropical Atlantic by an Indo-Pacific coral reef fish. Molecular Ecology 14: 3921-3928.

Rodriguez, L. 2006. Can invasive species facilitate native species? Evidence of how, when, and why these impacts occur. Biological Invasions 8: 927-939.

Roman, J. 2006. Diluting the founder effect: cryptic invasions expand a marine invader's range. Proceedings of the Royal Society BBiological Sciences 273: 2453-2459.

Roman, J., and J.A. Darling. 2007. Paradox lost: genetic diversity and the success of aquatic invasions. Trends In Ecology \& Evolution 22: 454-464.

Ross, D.J., C.R. Johnson, and C.L. Hewitt. 2002. Impact of introduced seastars Asteria amurensis on survivorship of juvenile commerical bivalves Fulvia tenuicostata. Marine Ecology Progress Series 241: 99-112.

Ruesink, J.L., B.E. Feist, C.J. Harvey, J.S. Hong, A.C. Trimble, and L.M. Wisehart. 2006. Changes in productivity associated with four introduced species: ecosystem transformation of a 'pristine' estuary. Marine Ecology Progress Series 311: 203-215.

Ruesink, J.L., H.S. Lenihan, A.C. Trimble, K.W. Heiman, F. Micheli, J.E. Byers, and M.C. Kay. 2005. Introduction of non-native oysters: ecosystem effects and restoration implications. Annual Review of Ecology, Evolution, and Systematics 36: 643-689.

Ruiz, G.M. and J.T. Carlton (eds.). 2003. Invasive Species: Vectors and Management Strategies. Washington, District of Columbia, USA: Island Press.

Ruiz, G.M., P. Fofonoff, A.H. Hines, and E.D. Grosholz. 1999. Nonindigenous species as stressors in estuarine and marine communities: assessing invasion impacts and interactions. Limnology and Oceanography 44: 950-972.

Ruiz, G.M., P.W. Fofonoff, J.T. Carlton, M.J. Wonham, and A.H.I. Hines. 2000a. Invasion of coastal marine communities in North America: apparent patterns, processes, and biases. Annual Review of Ecology and Systematics 31: 481-531.

Ruiz, G.M., T.K. Rawlings, F.C. Dobbs, L.A. Drake, T. Mullardy, A. Hug, and R.R. Colwell. 2000b. Global spread of microorganisms by ships. Nature 408: $49-50$.

Savini, D., and A. Occhipinti-Ambrogi. 2005. Consumption rates and prey preference of the invasive gastropod Rapana venosa in the Northern Adriatic Sea. Helgoland Marine Research 60: 153-159.

Sax, D.F., J.J. Stachowicz, and S.D. Gaines. 2005. Species invasions: insights into ecology, evolution and biogeography. Sunderland, MA: Sinauer Press.

Sax, D.F., J.J. Stachowicz, J.H. Brown, J.F. Bruno, M.N. Dawson, S.D. Gaines, R.K. Grosberg, A. Hastings, R.D. Holt, M.M. Mayfield, M.I. O'Connor, and W.R. Rice. 2007. Ecological and evolutionary insights from species invasions. Trends In Ecology and Evolution 22: 465-471.

Schneider, K.R., and B.N. Helmuth. 2007. Spatial variability in habitat temperature may drive patterns of selection between an invasive and native mussel species. Marine Ecology Progress Series 339: $157-167$.

Secord, D. 2003. Biological control of marine invasive species: cautionary tales and land-based lessons. Biological Invasions 5: $117-131$.

Shine, C., N. Williams, and L. Gundling 2000. A guide to designing legal and institutional frameworks on alien invasive species. International Union for the Conservation of Nature-The World Conservation Union, Gland, Switzerland. 
Shluker, A.D. 2003. State of Hawai'i Aquatic Invasive Species Management Plan. Department of Land and Natural Resources, Division of Aquatic Resources, Honolulu, Hawaii.

Simberloff, D. 2005. The politics of assessing risk for biology invasions: he USA as a case study. Trends in Ecology and Evolution 20: 216-222.

Simberloff, D., and B. Von Holle. 1999. Positive interactions of nonindigenous species: invasional meltdown? Biological Invasions 1: $21-32$.

Simons, M. 1997. A delicate Pacific seaweed is now a monster of the deep. New York, New York, USA: The New York Times.

Simpson, A., E. Sellers, A. Grosse, and Y. Xie. 2006. Essential elements of online information networks on invasive alien species. Biological Invasions 8: 579-1587.

Stachowicz, J.J., J.R. Terwin, R.B. Whitlatch, and R.W. Osman. 2002. Linking climate change and biological invasions: ocean warming facilitates nonindigenous species invasions. Proceedings of the National Academy of Sciences 99: 15497-15000.

Stevenson, J.C., and M.S. Kearney. (in press). Impacts of Global Climate Change and Sea-Level Rise on Tidal Wetlands. In Silliman, B. R., E. D. Grosholz and M. D. Bertness (eds), Anthropogenic Modification of North American Salt Marshes. University of California Press, Berkeley, California, USA.

Streftaris, N., A. Zenetos, and E. Papathanassiou. 2005. Globalisation in marine ecosystems: the story of non-indigenous marine species across European seas. Oceanography and Marine Biology Annual Review 43: 419-453.

Taylor, C.M., and A. Hastings. 2004. Finding optimal control strategies for invasive species: a density-structure model for Spartina alterniflora. Journal of Applied Ecology 41: 1049-1057.

Taylor, C.M., and A. Hastings. 2005. Allee effects in biological invasions. Ecology Letters 8: 895-980.

Thresher, R.E., and A.M. Kuris. 2004. Options for managing invasive marine species. Biological Invasions 6: 295-300.

Thuiller, W., D.M. Richardson, P. Pysek, G.F. Midgley, G.O. Hughes, and M. Rouget. 2005. Niche-based modelling as a tool for predicting the risk of alien plant invasions at a global scale. Global Change Biology 11: 2234-2250.

Trowbridge, C.D., and C.D. Todd. 2001. Host-plant change in marine specialist herbivores: ascoglossan sea slugs on introduced macroalgae. Ecological Monographs 71: 219-243.

Tyler, A.C., J.G. Lambrinos, and E.D. Grosholz. 2007. Nitrogen inputs promote the spread of an invasive marsh grass. Ecological Applications 17: 1886-1898.

Uchimura, M., A. Rival, A. Nato, R. Sandeaux, J. Sandeaux, and J.C. Baccou. 2000. Potential use of $\mathrm{Cu} 2+, \mathrm{K}+$ and $\mathrm{Na}+$ for the destruction of Caulerpa taxifolia: Differential effects on photosynthetic parameters. Journal of Applied Phycology 12: 15-23.

Van Beukering, P.J.H., and H. Cesar. 2004. Ecological economic modeling of coral reefs: evaluating tourist overuse at Hanauma bay and algae blooms at the Kihei coast, Hawai'i. Pacific Science 58: $243-251$.

Venter, O., N.N. Brodeur, B. Belland, I.J. Dolinsek, and J.W.A. Grant. 2006. Threats to endangered species in Canada. BioScience 56: 903-910.

Walters, L.J., K.R. Brown, W.T. Stam, and J.L. Olsen. 2006. Ecommerce and Caulerpa: unregulated dispersal of invasive species. Frontiers in Ecology and the Environment 4: 75-79.

Wallentinus, I., and C.D. Nyberg. 2007. Introduced marine organisms as habitat modifiers. Marine Pollution Bulletin 55: 323-332.

Weigle, S.M., L.D. Smith, J.T. Carlton, and J. Pederson. 2005. Assessing the risk of exotic species introductions via the live marine species trade. Conservation Biology 19: 213-223.

Williams, S.L. 2007. Introduced species in seagrass ecosystems: status and concerns. Journal of Experimental Marine Biology and Ecology 350: 89-110.
Williams, S.L., and S.L. Schroeder. 2004. Eradication of the invasive seaweed Caulerpa taxifolia by chlorine bleach. Marine Ecology Progress Series 272: 69-76.

Williams, S.L. and J.E. Smith. 2007. A global review of the distribution, taxonomy and impacts of introduced seaweeds. Annual Review of Ecology, Evolution, and Systematics 38: 327-359.

Withgott, J. 2002. California tries to rub out the monster of the lagoon. Science 295: 2201-2202.

Wittenberg, R., and M.J.W. Cock. 2001. Invasive alien species. how to address one of the greatest threats to biodiversity: a toolkit of best prevention and management practices. Wallingford, Oxon, United Kingdom: CAB International.

Wonham, M.J., J.T. Carlton, G.M. Ruiz, and L.D. Smith. 2000. Fish and ships: relating dispersal frequency to success in biological invasions. Marine Biology 136: 1111-1121.

Wonham, M.J., M. O'Connor, and C.D.G. Harley. 2005. Positive effects of a dominant invader on introduced and native mudflat species. Marine Ecology Progress Series 289: 109-116.

Wotton, D.M., C. O'Brien, M.D. Stuart, and D.J. Fergus. 2004. Eradication success down under: heat treatment of a sunken trawler to kill the invasive seaweed Undaria pinnatifida. Marine Pollution Bulletin 49: 844-849.

York, P.H., D.J. Booth, T.M. Glasby, and B.C. Pease. 2006. Fish assemblages in habitats dominated by Caulerpa taxifolia and native seagrasses in south-eastern Australia. Marine Ecology Progress Series 312: 223-234.

Zaleski, S.F., and S.N. Murray. 2006. Taxonomic diversity and geographic distributions of aquarium-traded species of Caulerpa (Chlorophyta: Caulerpaceae) in southern California, USA. Marine Ecology Progress Series 314: 97-108.

Zaitsev, Y.P. 1992. Recent changes in the trophic structure of the Black Sea. Fisheries Oceanography 1: 180-189.

Zipperer, V.T. 1996. Ecological effects of the introduced cordgrass, Spartina alterniflora, on the benthic community structure of Willapa Bay, Washington. M. S. Thesis, University of Washington, Seattle, Washington, USA.

\section{Sources of Unpublished Materials}

Chang, A. (andchang@ucdavis.edu) University of California at Davis, Davis, California.

Chang, E. S. (eschang@ucdavis.edu) Bodega Marine Laboratory, University of California at Davis, Bodega Bay, California 94923.

Ellis, S. (sellis@dfg.ca.gov) State Invasive Species Coordinator, California Department of Fish and Game, 1416 Ninth Street, Suite, 1260, Sacramento, California 95814.

Lovell, S., E. Besedin and E. D. Grosholz. 2007. Modeling economic impacts of the European green crab. Working paper submitted to the American Agricultural Economics Association Meetings, Portland, Oregon.

Tyler, A. C. and E. D. Grosholz. In review. Spartina invasion changes intertidal ecosystem metabolism in San Francisco Bay. Proceedings of the Third Annual Invasive Spartina Conference. Cambridge Publications, San Francisco, California.

Wecker, M. (mwecker@u.washington.edu) Olympic Natural Resources Center, University of Washington.

Paznokis, W. Staff Environmental Scientist, California Department of Fish and Game, 4949 Viewridge Avenue, San Diego, California 92123. (858- 467-2067).

Weiskel, H. W. (hwweiskel@ucdavis.edu) University of California at Davis; http://www.des.ucdavis.edu/faculty/grosholz/people/ weiskel.htm.

Zabin, C. (zabinc@si.edu) Smithsonian Environmental Research Center. 